\title{
Stabilization of Bilirubin Oxidase in a Biogel Matrix for High-performance Gas Diffusion Electrodes
}

\author{
Graziela C. Sedenho, Ayaz Hassan, Lucyano J. A. Macedo and Frank N. Crespilho* \\ São Carlos Institute of Chemistry, University of São Paulo (USP), Avenida Trabalhador São- \\ carlense, 400, São Carlos, SP 13560-970, Brazil. \\ *Corresponding author: frankcrespilho@iqsc.usp.br; +55 1633738783.
}

\begin{abstract}
Enzyme immobilization on solid conducting surfaces faces some challenges for practical applications in technologies such as biosensors and biofuel cells. Short-term stability, poor electrochemical performance, and enzyme inhibition are some issues that remain unsolved. Here, we propose a simple methodology for bilirubin oxidase (BOD) immobilization on carbon-based gas-diffusion electrodes for a four-electron electrochemical oxygen reduction reaction (ORR). The enzyme is incorporated into a Nafion ${ }^{\circledR}$ polymeric matrix and cross-linked with glutaraldehyde by a one-pot reaction in a buffered solution, producing a stable BOD-based biogel. The biogel prevents the formation of enzyme aggregates, producing a homogeneous bioelectrode surface, and allows access to the direct electron-transfer mechanism of multicopper centers buried in the enzyme. A biocatalytic reduction current of $-1.52 \pm 0.24 \mathrm{~mA} \mathrm{~cm}^{-2}$ at $0.19 \pm 0.06 \mathrm{~V}$ was observed under gas-diffusion conditions. Additionally, the bioelectrode showed an unprecedented long-term stability under continuous operation combined with satisfactory catalytic current without redox mediator, demonstrating that the BOD-based biogel provides a suitable microenvironment for long-term enzymatic activity involving a bio-three-phase interfacial reaction. Therefore, the present study contributes new insights into enzyme immobilization to overcome the critical shortterm stability issue of enzyme-based electrochemical devices for practical applications.
\end{abstract}

Keywords: Bilirubin oxidase, Gas-diffusion electrode, Enzyme immobilization, Oxygen reduction reaction, Direct electron transfer. 


\section{INTRODUCTION}

The term "enzyme immobilization" was first used in 1971 to designate "enzymes physically confined or localized in a certain defined region of space with retention of their catalytic activities, and which can be used repeatedly and continuously."(Katchalski-katzir, 1993) The use of immobilized enzymes in biocatalysis is of great interest in several areas, such as industrial processes and biodevices, because the anchoring of the enzyme on the support facilitates the handling of the enzyme, may solve the solubility problem of some enzymes, and enable the recovery and re-use of the enzyme.(Sheldon and Pelt, 2013) However, to be attractive, the enzyme immobilization method should be easy, inexpensive, and reproducible. Especially in the development of electrochemical biodevices, such as biofuel cells (BFCs) and biosensors, the enzyme immobilization on the electrode surface plays a crucial role in achieving high-performance systems.(Luz et al., 2014; Rasmussen et al., 2016; Xiao et al., 2019; Yates et al., 2018) This is because the method of enzyme immobilization should promote an effective electronic connection between the redox site of the protein and the electrode surface, preserve the catalytic activity and the integrity of the enzyme long-term, and allow an efficient substrate mass transport to the biocatalysts.(Luz et al., 2014; Rasmussen et al., 2016; Xiao et al., 2019; Yates et al., 2018)

Adsorption by the drop-casting method is a traditional approach used to immobilize redox enzymes on electrode surfaces,(Poulpiquet et al., 2015; Santoro et al., 2016; So et al., 2016a, 2016b; Tsujimura et al., 2005a; Xia et al., 2016) because it is simple, fast, inexpensive, and suitable for different types of electrode materials and surfaces. However, because of the omnipresent coffee-ring effect, this method creates biocatalyst aggregates,(Li et al., 2018) which may contribute to a poor surface homogeneity, poor electrical communication and kinetic losses, and unsatisfactory cohesion due to the weak forces that keep the biomolecules adsorbed on the electrode surface, harming the electrode stability. A simple strategy to minimize the enzyme desorption from the electrode surface is by physical entrapment in a polymeric matrix or gel, for example Nafion ${ }^{\circledR}$ and chitosan,(Klotzbach et al., 2008) but these materials can represent a

diffusion barrier.(Luz et al., 2014) Chemical binding between the functional groups of the enzyme molecules (crosslinking) and/or electrode surface covalent immobilization are alternative strategies to overcome the issues related to the biocatalyst leakage and mass transport, but they cause high enzyme activity loss.(Luz et al., 2014) Therefore, the development of robust and 
efficient bioelectrodes requires special attention to the method of enzyme immobilization, which will depend on the type of enzyme and substrate involved.

The enzyme immobilization should be carefully evaluated in oxygen reduction reactions (ORR) catalyzed by multicopper oxidases (MCOs), such as bilirubin oxidase (BOD) and laccase, because a gas substrate is involved. It is well known that the utilization of gas-diffusion electrodes (GDEs) is extremely attractive, because they allow the gas permeability through a hydrophobic layer to reach the hydrophilic catalytic layer usually composed of MCOs immobilized on materials such as carbon nanotubes and carbon nanoparticles.(Ciniciato et al., 2012; Gupta et al., 2011a; Lalaoui et al., 2016; Lau et al., 2012; Poulpiquet et al., 2015; Santoro et al., 2016; So et al., 2016b) In this configuration, high catalytic current densities for ORR, even without redox mediators, have been reached.(Lalaoui et al., 2016; So et al., 2016b)

Despite considerable advances in bioelectrodes for ORR, some limitations remain. The underappreciated long-term stability and robustness restrict the use of BFCs in the medical field or in others that require a long-term application. In this context, here, we present a simple and efficient method for the immobilization and stabilization of BOD onto a carbon-based electrode by its incorporation into a gel matrix for efficient ORR in GDE. The gel matrix prevents the formation of enzyme aggregates by the coffee-ring effect, creates a suitable microenvironment for long-term enzyme activity, and simultaneously promotes a bio-three-phase involved in the ORR: a gas phase, where the reacting molecular oxygen is present; the solid phase, composed of the biocatalyst; and the aqueous liquid electrolyte, which is important for enzyme functioning and is the destination of the reaction product.

\section{EXPERIMENTAL}

\subsection{Materials}

BOD (EC 1.3.3.5) from Myrothecium sp. was purchased from Amano Enzyme Inc. and used without further purification. The GA solution (25\%), Nafion ${ }^{\circledR} 117$ solution (5\%), carbon nanopowder (<500 nm, 50-250 $\left.\mathrm{m}^{2} \mathrm{~g}^{-1},>99.95 \%\right)$, nitric acid (70\%), and isopropanol (99.5\%) were obtained from Sigma-Aldrich. The poly(1,1,2,2-tetrafluoroethylene) suspension (PTFE T-30, $60 \%$ ) was purchased from DuPont. The carbon black (Vulcan XC-72) was purchased from Cabot, and the carbon cloth was obtained from Stackpole Electronics, Inc. Prior to use, the carbon black 
and the carbon cloth were cleaned by a heating treatment at $450{ }^{\circ} \mathrm{C}$ in ambient atmosphere, followed by chemical treatment at $80{ }^{\circ} \mathrm{C}$ for $1 \mathrm{~h}$ with a $25 \%(\mathrm{v} / \mathrm{v})$ nitric acid solution. The phosphate buffer solution, pH $7.2\left(0.10 \mathrm{~mol} \mathrm{~L}^{-1}\right)$, was prepared with sodium phosphate monobasic (98-102\%) and sodium phosphate dibasic (98-102\%), which were obtained from Synth. All solutions were prepared with deionized water.

\subsection{BOD-based biogel preparation}

Initially, the Nafion ${ }^{\circledR} 117$ solution (5\%) was diluted in the phosphate buffer, pH 7.2, at a 1:1 (v/v) ratio to obtain a Nafion salt solution and to prevent denaturation of the enzyme by local acidification.(Macedo et al., 2020) The GA solution (25\%) was also diluted in the phosphate buffer

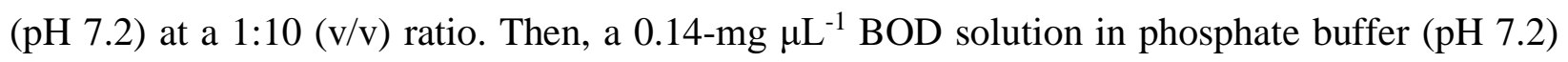
was mixed with the Nafion diluted salt solution and GA diluted solution at a 1:1:1 (v/v/v) ratio. Afterward, this mixture was kept at $4{ }^{\circ} \mathrm{C}$ for three hours in order to obtain the biogel (see Fig. 1a).

\subsection{BOD-based biogel/C GDE preparation}

The gas-diffusion layer (GDL) was prepared as previously described by Paganin et al.(Paganin et al., 1996) A homogeneous aqueous suspension composed of $70 \%(\mathrm{w} / \mathrm{w})$ carbon black and 30\% (w/w) PTFE was filtered under vacuum onto one face of the pre-treated carbon cloth to form the GDL using a loading (carbon+PTFE) of $3.0 \mathrm{mg} \mathrm{cm}^{-2}$. Next, the carbon+PTFE layer was baked onto the carbon cloth at $280{ }^{\circ} \mathrm{C}$ for $30 \mathrm{~min}$ to remove the dispersion agent contained in the PTFE suspension. Finally, it was sintered at $330{ }^{\circ} \mathrm{C}$ for $30 \mathrm{~min}$, to obtain a thin film GDL over the entire surface of the carbon cloth.(Klinedinst et al., 1976) After the preparation of the GDL, a suspension of carbon nanoparticles in isopropanol was dropped onto the top of it and homogenously spread with a brush until a loading of $1.0 \mathrm{mg} \mathrm{cm}^{-2}$ was obtained. After that, the isopropanol was dried under atmospheric conditions for approximately $2 \mathrm{~h}$. Next, $36.3 \mu \mathrm{L}$ of the previously prepared BOD-based biogel were dropped onto the top of the carbon nanoparticle layer (geometric area $=1.18 \mathrm{~cm}^{2}$ ) to form the catalytic layer. Prior to use, the electrode was incubated at $4{ }^{\circ} \mathrm{C}$ overnight. An array of flexible carbon fibers was used as the electrical contact. The actual photo and schematic representation of the BOD-based biogel/C GDE are shown in Fig. 1b. 


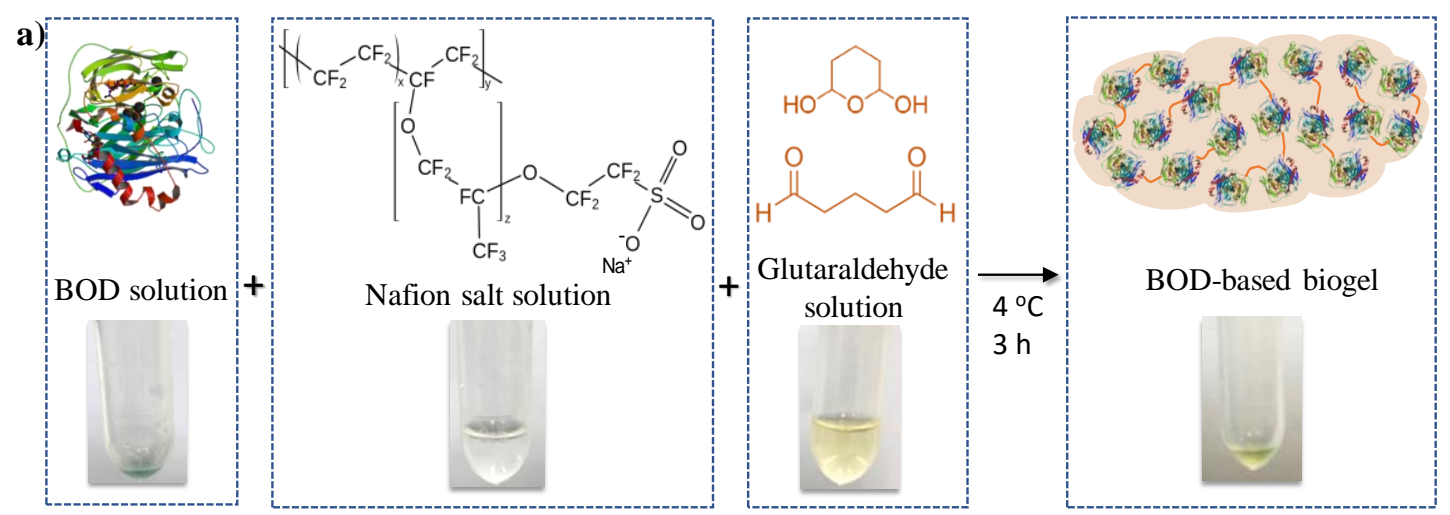

b)

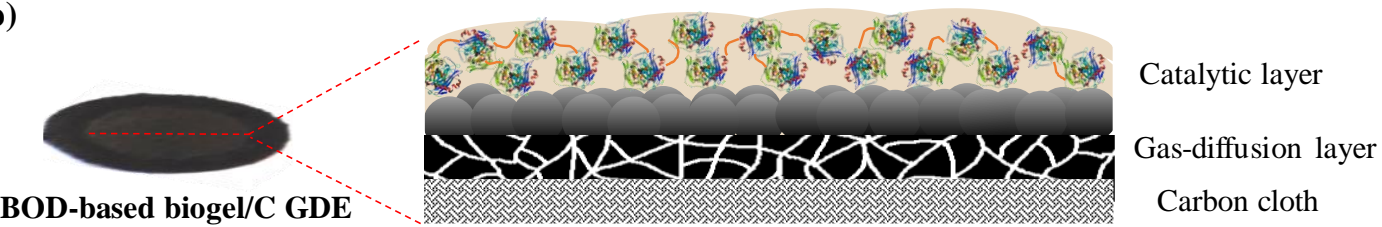

Figure 1. (a) Scheme of one-pot reaction for obtaining BOD-based biogel and (b) photo and schematic representation of BOD-based biogel/C GDE.

\subsection{Scanning electron microscopic measurements}

The samples were covered with a 6-nm-thick Au layer and kept in a desiccator until the analysis. SEM images were obtained using a FEI Magellan 400 L field-emission scanning electron microscope. The obtained images were used to evaluate the detailed morphology of the electrode surface.

\subsection{Micro-FTIR spectroscopic experiments}

For micro-FTIR spectroscopic measurements, seven different samples, including GA, Nafion salt and BOD, the binary mixtures Nafion+GA, BOD+Nafion and BOD+GA, and BODbased biogel containing all three constituents in phosphate buffer $(\mathrm{pH}$ 7.2), were prepared. Approximately $2 \mu \mathrm{L}$ of each sample were initially drop-casted on the surface of a clean goldcoated glass substrate and on a glassy carbon (GC) plate, incubated at $4{ }^{\circ} \mathrm{C}$ overnight, and then dried in vacuum before analysis. The vibrational spectra were recorded in the reflectance mode using a Hyperion 3000 (Bruker) microscope coupled to a Vertex 70v FTIR spectrometer (Bruker). Each spectrum is a resultant of 32 scans with a spectral resolution of $4 \mathrm{~cm}^{-1}$. The absorption signals corresponding to the background were subtracted from the spectra of the samples. 
FTIR chemical images were collected using a $64 \times 64$ element liquid $\mathrm{N}_{2}$-cooled focal plane array (FPA) detector. Each element of the FPA works as an individual detector, making the measurement of a full spectrum from a single point with a spatial resolution of $2.7 \mu \mathrm{m}$ possible when a $15 \times$ objective is used. Thus, this experimental setup allows the simultaneous collection of 4096 spectra, as previously reported.(Macedo and Crespilho, 2018) To obtain the chemical maps, the area under an absorption band corresponding to a characteristic functional group from the sample was integrated and a color-coded image was built. Here, the blue color in the chemical maps represents regions in the sample with the lowest concentration of the compound of interest, and the pink color shows regions with the highest concentration of each particular signal. These chemical images were obtained in order to investigate the homogeneity and spatial distribution of the components in the BOD-based biogel.

\subsection{Electrochemical measurements}

Electrochemical measurements were performed using an Autolab PGSTAT128N (Metrohm, Switzerland) galvanostat/potentiostat apparatus. The electrochemical measurements under nongas-diffusion conditions were performed in a conventional electrochemical cell thermostated with a water jacket. Conversely, the electrochemical measurements under the gas-diffusion condition were performed in a homemade glass electrochemical cell, as shown in Fig. S1. In this configuration, the catalytic layer (geometric area $=1.18 \mathrm{~cm}^{2}$ ) of the BOD-based biogel/C GDE working electrode faces the electrolyte and the carbon cloth faces the air. A platinum mesh and an $\mathrm{Ag} / \mathrm{AgCl} / \mathrm{KCl}_{\text {sat }}$ were used as the counter and reference electrodes, respectively. The measurements were performed in a phosphate buffer, $\mathrm{pH} 7.2\left(0.10 \mathrm{~mol} \mathrm{~L}^{-1}\right)$, under quiescent and atmospheric conditions. The temperature was controlled by using a thermostatic bath (GEMultiTemp IV Thermostatic Circulator, $0.01{ }^{\circ} \mathrm{C}$ resolution).

For the rotatory disc electrode (RDE) experiments, a Pine Instruments Rotator (Pine Research Instrumentation, USA) coupled to an Autolab PGSTAT128N (Metrohm, Switzerland) galvanostat/potentiostat was used. A GC electrode (from Pine Research Instrumentation, USA) with geometric area equal to $0.196 \mathrm{~cm}^{2}$ was employed as the working electrode. Prior to the measurements, the GC electrode was polished in alumina $0.05 \mu \mathrm{m}$, sonicated in deionized water

for $5 \mathrm{~min}$, and then dried in a $\mathrm{N}_{2}$ atmosphere. A suspension of carbon nanoparticles was dropped onto the GC surface until the load of $1.0 \mathrm{mg} \mathrm{cm}^{-2}$ was attained, as previously described. Next, an 
appropriate volume of the previously prepared BOD-based biogel was dropped onto the top of the carbon nanoparticle layer. The electrode was incubated at $4{ }^{\circ} \mathrm{C}$ overnight before the measurements.

\section{RESULTS AND DISCUSSION}

\subsection{Crosslinking between the components of the BOD-based biogel}

FTIR spectroscopy in the mid-region is a sensitive technique for probing the structural changes of bio-organic compounds based on the changes observed in the spectral band positions and their intensities. The FTIR spectra of the BOD-based biogel, its individual components, and binary mixtures recorded in the reflectance mode are shown in Fig. 2a. The vibrational assignments of the absorption signals observed in the spectra of the individual components are given in Table S1, according to previous reports.(Barth, 2007; Guo et al., 2010; Hu et al., 2013; Kil'deeva et al., 2009; Kishore et al., 2012; Ramaswamy et al., 2009) The characteristic vibrational modes corresponding to the specific functional groups of each compound are clearly observed in the respective spectra (Fig. S2). For example, the FTIR spectrum of the GA shows absorption signals at 1713 and $1128 \mathrm{~cm}^{-1}$ that are attributed to $\mathrm{C}=\mathrm{O}$ stretching and deformation modes, respectively,(Hu et al., 2013; Kil'deeva et al., 2009) which indicate the presence of a free aldehyde form in the conditions that the biogel was prepared. In addition, the signals at 1677 and $1063 \mathrm{~cm}^{-}$

${ }^{1}$ are assigned to $\mathrm{O}-\mathrm{H}$ bending and $\mathrm{C}-\mathrm{O}$ (from alcohol) stretching vibrational modes and indicate the cyclization of GA (Eq. S1).(Torres et al., 2014) With regard to Nafion, the characteristic absorption signals are observed at 980 (C-O-C stretching), 1060, and $1315 \mathrm{~cm}^{-1}$, (sulfonic group symmetric and asymmetric stretching, respectively), 1150 and $1233 \mathrm{~cm}^{-1}\left(\mathrm{CF}_{2}\right.$ symmetric and asymmetric stretching, respectively).(Ramaswamy et al., 2009) Likewise, in the spectrum of the BOD sample, the characteristic amide-I and amide-II vibrational modes can be observed at 1663 and $1543 \mathrm{~cm}^{-1}$, respectively.(Barth, 2007) 

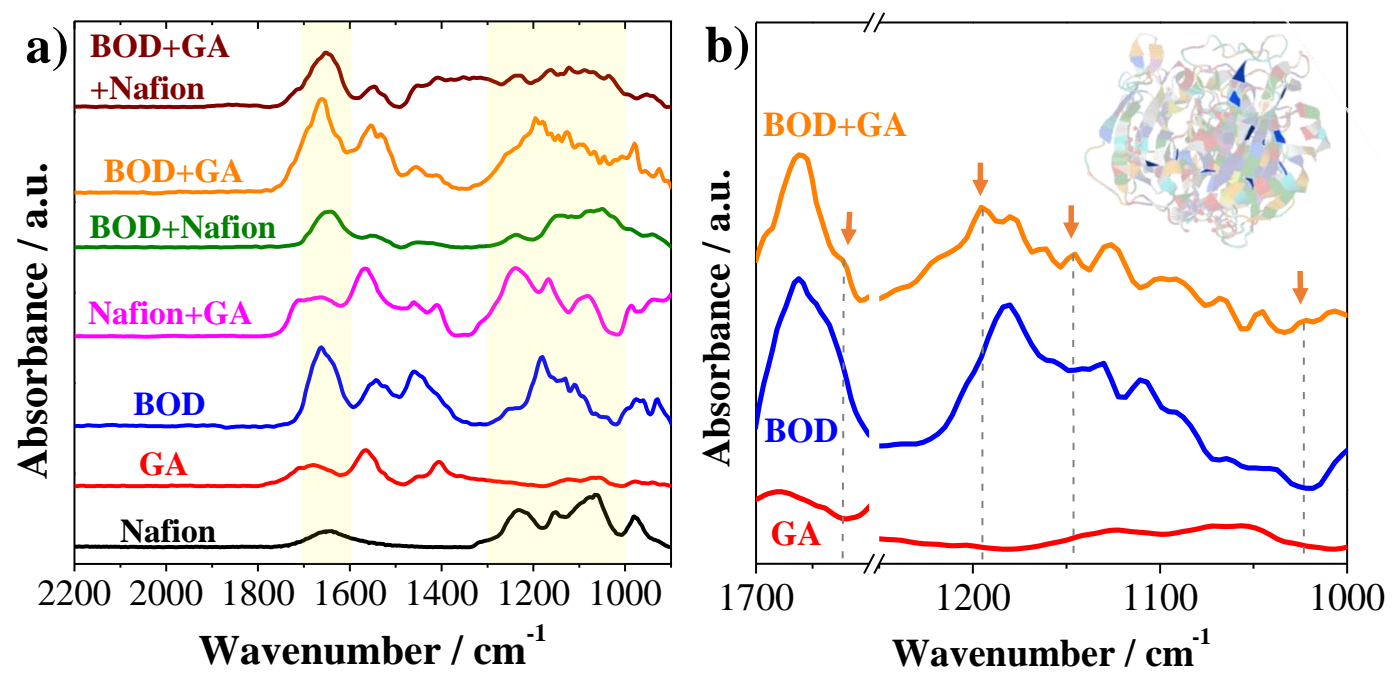

Figure 2. (a) FTIR spectra of the components of the BOD-based biogel. (b) Zoom view of the spectra of GA, BOD, and BOD+GA. Inset: BOD three-dimensional structure with highlighted lysine residues in blue, PDB: 2XLL.

Most of the above-mentioned absorption signals in the GA, Nafion, and BOD spectra are also observed in the mixtures of these components. Nevertheless, the interaction between some of the components of the biogel was confirmed from the appearance of some peaks in the FTIR spectra of the mixtures that are not present in the spectra of the individual components. For instance, some new peaks appear at various positions in the FTIR spectrum of the mixture of GA+BOD when compared to the individual spectra of each component, as shown in Fig. 2b. The emergence of the peaks at $1620,1196,1144$, and $1022 \mathrm{~cm}^{-1}$ are possibly due to the $\mathrm{C}=\mathrm{N}$ stretching mode in the first case and $\mathrm{C}-\mathrm{N}$ stretching modes in the latter cases (Eqs. S2-S3). These vibrational modes indicate the crosslinking of enzyme molecules through the reaction with GA. The aldehyde functional groups in GA are expected to form Schiff bases upon nucleophilic attack by the sidechain amino group of lysine residues of BOD (see inset in Fig. 2b).(Migneault et al., 2004)

However, no significant changes are observed in the FTIR spectra when Nafion is combined with GA or BOD, as visualized in Fig. S3. Finally, the spectrum of the biogel exhibits practically the same profile as the mixture of GA and BOD, alongside some features from Nafion, suggesting that the same kind of interaction occurs in the biogel as in the mixtures of GA and BOD and no chemical bonds are formed between Nafion and the other components of the biogel. These observations are expected, and they confirm that Nafion works only as a polymeric network for physical entrapment of BOD. 


\subsection{BOD-based biogel homogeneity}

The homogeneity of a BOD-based biogel film compared with a film of bare-BOD in a phosphate buffer was qualitatively evaluated by optical microscopy (reflectance mode) and microFTIR spectroscopy (Fig. 3a). A bare BOD-film (Fig. 3b-c) and BOD-based biogel (Fig. 3d-e) were assembled on a gold-coated glass substrate by drop-casting a few microliters of each sample onto the substrate. The difference in contrast across the optical microscopic images can be related to the local concentrations and local thicknesses of the samples. Figure 3a shows a thin and uniform film of BOD-based biogel on the gold substrate, without any visible aggregate over the border area (Fig. 3e). Some aggregates are observed in the inner region of the droplet (Fig. 3d), which are caused by the phosphate salt crystallization, as the sample was fully dried before analysis, or nonreacting GA. Conversely, the microscopic images of the bare BOD-film on the gold substrate (Fig. 3b-c) reveal ring-shaped structures indicated by a darker contrast over the border and in the inner region of the droplet, where enzyme molecules were accumulated. In addition, phosphate salt precipitate is also observed in the bare BOD film. The deposition of matter along the original drop edge after the evaporation of a solvent is known as the coffee-ring effect.(Mampallil and Eral, 2018) This phenomenon has been reported during the redox enzyme immobilization(Li et al., 2018) and happens during the solvent evaporation, when the edges of the drop become pinned to the solid substrate, and the outward capillary flow from the center of the drop brings the nonvolatile component to the edge of the droplet.(Crivoi and Duan, 2013) Characteristics similar to those of the BOD-based biogel and bare-BOD films immobilized on the gold substrate are also obtained for the glassy carbon (GC) platform; the BOD-based biogel film (Fig. S3a-b) shows some salt aggregates and no coffee-ring feature, whereas a ring-like deposit is observed for the bare-BOD film (Fig. S3c-d) on the carbon-based platform. These observations indicate the interactions between the BOD molecules by the crosslinking via the reaction with GA, and its entrapment into a Nafion network prevents the BOD agglomeration during the enzyme immobilization on the gold and GC substrates, which can be used as electrode surfaces.

The micro-distribution of the compounds in the biogel was investigated by micro-FTIR chemical imaging (Fig. 3f-h). The red square area in Fig. 3e was selected for the collection of the spectra to build the chemical images. The FTIR spectrum of the BOD-based biogel in Fig. $3 f$ 
highlights the bands that are mostly attributed to BOD and Nafion; these bands were integrated to obtain the spatial distributions (Fig. 3g-h) of these components in the biogel. No specific absorption signal could be assigned only to GA; therefore, its distribution within the biogel could not be investigated. The chemical map in Fig. 3g shows a homogenous distribution of BOD within the biogel sample. A similar type of distribution is observed for Nafion in Fig. 3h, which suggests that Nafion and BOD are present adjacent to each other in the structure of the biogel, and are also favorable for a higher bioelectrochemical performance owing to a more effective mass transport of oxygen toward the enzymes.

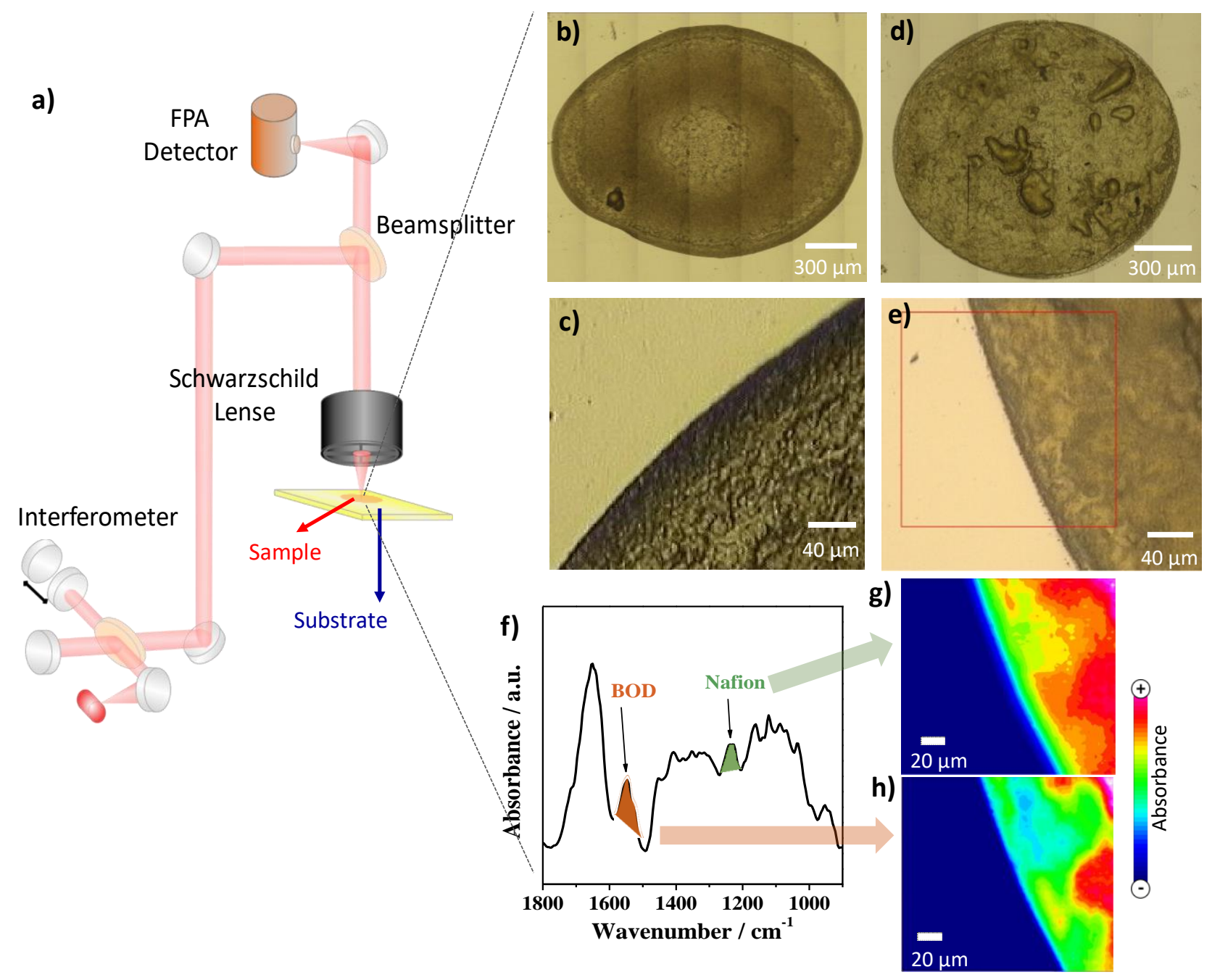

Figure 3. (a) Micro-FTIR setup with FPA detector. (b-e) Optical images of the bare-BOD film (b, c) and BOD-based biogel (d, e) on gold-coated glass substrate. The red square indicates the area selected to record the spectra and used to build the chemical images. (d) FTIR spectrum of the BOD-based biogel showing the signals integrated for obtaining the chemical images. $(\mathrm{g}, \mathrm{h})$ Chemical images showing the distribution of $1543 \mathrm{~cm}^{-1}$ (amide-II) and $1233 \mathrm{~cm}^{-1}\left(\mathrm{CF}_{2}\right.$ asymmetric stretching) spectral bands of BOD and Nafion, respectively. 


\subsection{Bioelectrochemical performance of BOD-based biogel/C electrode}

The electrochemical behavior of the BOD-based biogel/C electrode was first investigated by cyclic voltammetry (CV) in the absence of oxygen. The CV curve in Fig. 4a shows two distinctive redox couples that are absent in the enzyme-free electrode. The redox couple I/II with formal potential $\left(E^{\circ}\right)$ equal to $0.51 \mathrm{~V}$ (all potentials reported here are referenced to $\mathrm{Ag} / \mathrm{AgCl} / \mathrm{KCl}$ sat ) is attributed to the $\mathrm{Cu}^{+} / \mathrm{Cu}^{2+}$ redox reaction in the T1 site of BOD, which is the primary center where electrons from the electrode are received.(Christenson et al., 2006; Schubert et al., 2009; Tsujimura et al., 2005b) The second redox couple with $E^{\mathrm{o}}$ equal to $0.16 \mathrm{~V}$ is in good agreement with the data reported for reduction and oxidation of the T2/T3 $\mathrm{Cu}$ center of the enzyme,(Ivnitski et al., 2008) which acts as an electronic bridge in the internal electron transfer mechanism to promote the reduction of dioxygen.(Macedo et al., 2020) As previously reported, the peaks corresponding to reduction and oxidation of the $\mathrm{T} 1 \mathrm{Cu}$ site are less defined in neutral media as a result of the change of bond length between this $\mathrm{Cu}$ atom and the ligand groups and the special arrangement of this site.(Ivnitski et al., 2008; Ramírez et al., 2008) These results indicated an efficient direct electrical communication between the enzyme and the carbon nanoparticles, which is usually desirable in enzyme-based BFCs and biosensors. Therefore, we demonstrate the direct electron-transfer (DET) between BOD and nonfunctionalized carbon particles, which had been previously only observed

on gold electrodes, ${ }^{22}$ carbon nanotube-based electrodes,(Ivnitski et al., 2008; Lalaoui et al., 2016, 2015; Lopez et al., 2014; Poulpiquet et al., 2015; Schubert et al., 2009; So et al., 2016b; Weigel et al., 2007) and spectrographic graphite electrodes.(Ramírez et al., 2008; Shleev et al., 2004) 

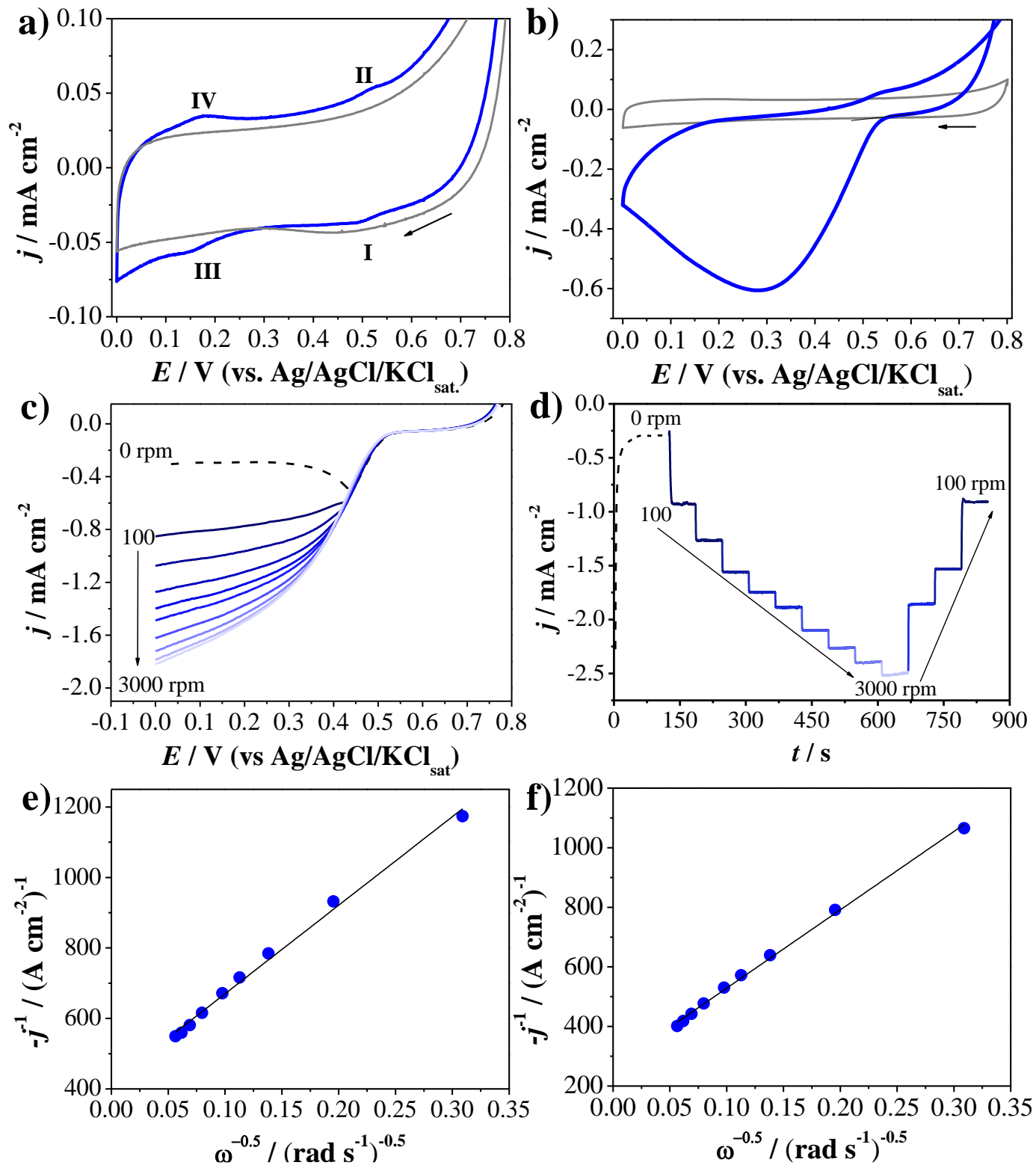

Figure 4. $\mathrm{CVs}$ at $5 \mathrm{mV} \mathrm{s}^{-1}$ in phosphate buffer $\mathrm{pH} 7.2$ at $25^{\circ} \mathrm{C}$ obtained with BOD-based biogel/C electrode (blue curves) and enzyme-free electrode (gray curves) in absence of $\mathrm{O}_{2}$ (a) and in electrolyte saturated with $\mathrm{O}_{2}$ (b). The arrows indicate the potential scan direction. (c) Linear voltammograms at $5 \mathrm{mV} \mathrm{s}^{-1}$ and (d) chronoamperogram at $0.00 \mathrm{~V}$ of BOD-based biogel/ $/ \mathrm{C}^{\text {in } \mathrm{O}_{2-}}$ saturated phosphate buffer $\mathrm{pH} 7.2$ at $25{ }^{\circ} \mathrm{C}$, at quiescent condition (dashed lines) and under different electrode rotation rates $(100,250,500,750,1000,1500,2000,2500$, and $3000 \mathrm{rpm}$, solid lines). Koutecky-Levich plots obtained from linear voltammograms (e) and chronoamperograms (f).

The reduction of dissolved dioxygen in phosphate buffer ( $\mathrm{pH}$ 7.2) catalyzed by BOD was initially investigated by CV. Figure $4 \mathrm{~b}$ shows the $\mathrm{CV}$ obtained with the BOD-based biogel/C electrode in the presence of $\mathrm{O}_{2}$ dissolved in the electrolyte and in the absence of $\mathrm{O}_{2}$ for comparison. 
In the presence of $\mathrm{O}_{2}$, a large cathodic wave with onset potential at ca. $550 \mathrm{mV}$ is observed, which is very close to the thermodynamic potential of ORR to water $\left(607 \mathrm{mV}\right.$ vs. $\mathrm{Ag} / \mathrm{AgCl} / \mathrm{KCl}_{\text {sat }}, \mathrm{pH}$ 7.2) and agrees with the previously reported potential of non-mediated ORR catalyzed by BOD.(Gupta et al., 2011b; Ramírez et al., 2008) In contrast, on an enzyme-free carbon electrode, the ORR occurs with high overpotential, with onset potential at ca. $-40 \mathrm{mV}$ (Fig. S5). The peakshaped catalytic wave observed in Fig. 4b indicates that the electrochemical process is controlled by the diffusion of $\mathrm{O}_{2}$ species toward the electrode surface. The mass transport effect is evident when the electroactive coverage of the enzyme is very high, and often occurs when the enzyme is embedded in a gel or if a very rough surface is employed, such as that made by nanoparticulated materials.(Dos Santos et al., 2010)

In order to investigate the effect of the mass transport of $\mathrm{O}_{2}$ and obtain information about the bioelectrochemical reaction, experiments with RDE were performed. Figure 4c shows the linear voltammograms obtained with a BOD-based biogel/C electrode at different rotation rates. Typical and sigmoidal cathodic waves are observed under RDE conditions. It can be seen that in the potential range from 0.55 to $0.45 \mathrm{~V}$, the current densities are independent of the electrode rotation rate, which indicates that in this potential range the observed current densities are almost purely controlled by electron-transfer kinetics.(Xing et al., 2014) At high overpotentials (potentials close to $0 \mathrm{~V}$ ), where the interfacial electron transfer is very fast, the reduction currents increase gradually with the electrode rotation rate, indicating a diffusion-convection control. Figure $4 \mathrm{~d}$ presents the chronoamperograms at $0.00 \mathrm{~V}$ of the BOD-based biogel/C electrode under RDE conditions, where the dependence of the limiting current on the increase and decrease of the electrode rotation rate can be observed. The stability of the BOD-based biogel/C electrode is demonstrated by the agreement between the limiting reduction currents at the same rotation rate in the beginning and at the end of the experiments (Fig. 4d). From Koutecky-Levich plots (Figs. 4e-f) and the Levich equation (Eq. S4), the number of electrons involved in the ORR was calculated to be $3.9 \pm 0.2$ (95\% of confidence interval, 3 degrees of freedom), as expected for the ORR catalyzed by BOD, even at near $\mathrm{pH} 7$. 


\subsection{BOD-based biogel/C GDE electrode}

Because the catalytic current is limited by the slow diffusion of $\mathrm{O}_{2}$ species toward the electrode surface and by the very low solubility of these reacting species in aqueous solution, the use of a gas-diffusion biocathode is imperative to reach high-performance biodevices, such as BFCs and bioreactors.(Horst et al., 2016; So et al., 2017b) In this context, the BOD-based biogel/C (catalytic layer) was assembled onto a hydrophobic GDL supported on the carbon cloth to form the GDE, as shown in Fig. 1b. The SEM images of the GDL in Fig. 5a show the presence of PTFE strands that promote the agglomeration of the carbon black nanoparticles, providing a porous structure formed by microstructured channels (Fig. 5a), which allow for the efficient supply of $\mathrm{O}_{2}$. In addition, the combination of carbon black and PTFE simultaneously ensures electrical conductivity, mechanical stability, and water repellency for the electrode. Additionally, carbon nanoparticles deposited on the top of the GDL provide a higher effective surface area for enzyme immobilization and high electrical conductivity. The SEM images of this layer in Fig. 5b show near spherical carbon nanoparticles with a diameter of $38 \pm 2 \mathrm{~nm}$ (Fig. S6).

The SEM images displayed in Fig. 5c show a dense, thick, and homogenous layer of the BOD-based biogel on top of the carbon nanoparticles. Additionally, the presence of several cracks in this layer is observed, which can generate the bio-three-phase interface (as represented in Fig. 6a): gas phase, where the reacting molecular oxygen is present; the solid phase, where the biocatalyst is present; and the aqueous liquid electrolyte, which is important for enzyme functioning and is the destination of the reaction product. 

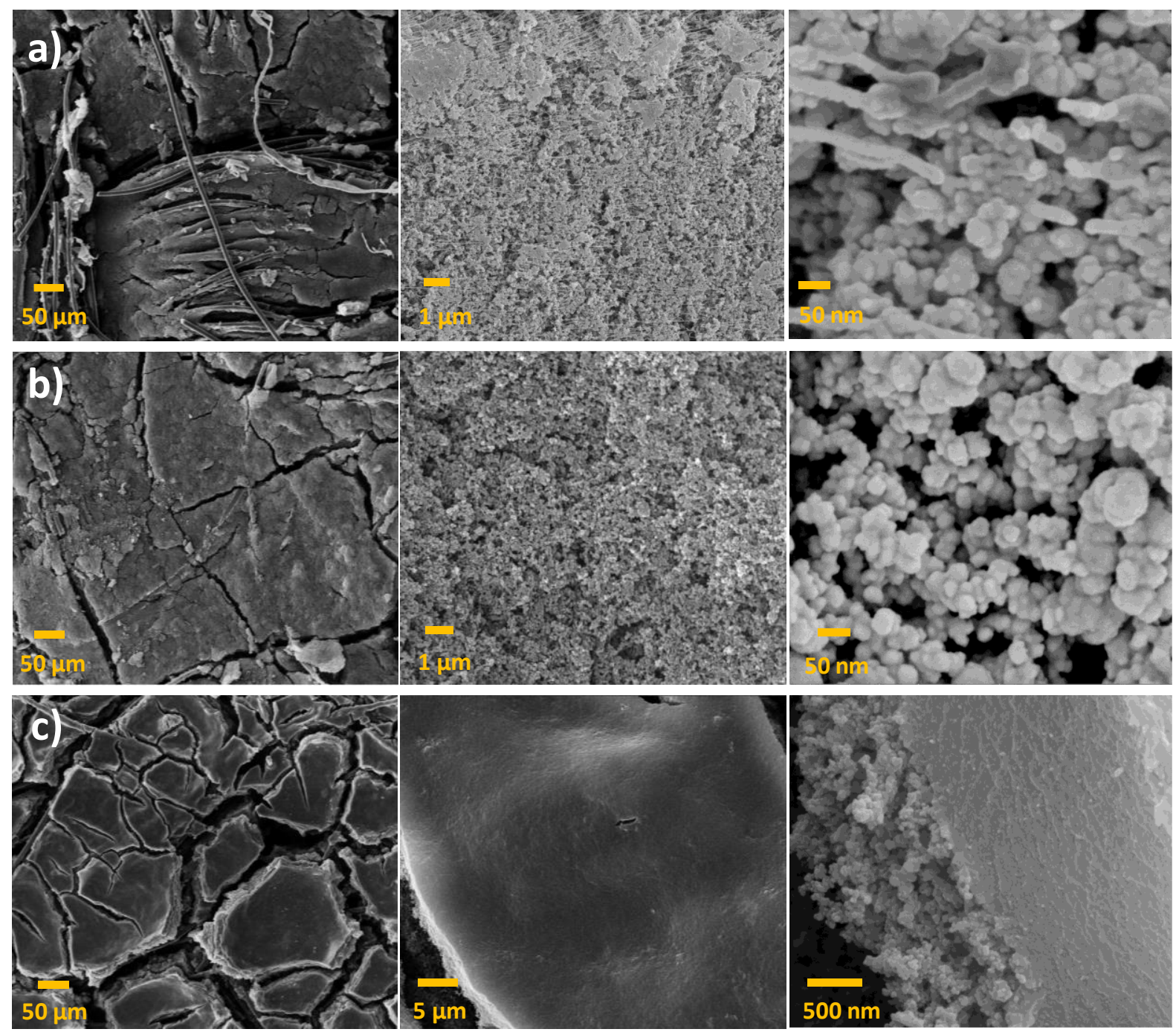

Figure 5. SEM images at different magnifications of the (a) GDL, (b) carbon nanoparticles, and (c) BOD-based biogel on the GDE.

The electrochemical performance of the BOD-based biogel/C GDE toward the ORR was evaluated under atmospheric conditions. Figure $6 \mathrm{~b}$ shows the $\mathrm{CV}$ obtained with the BOD-based biogel/C GDE, where we observe an onset potential value of ca. $555 \mathrm{mV}$ for ORR, which agrees well with the onset potential value of the reduction reaction of $\mathrm{O}_{2}$ dissolved in the electrolyte (Fig. $\left.4 \mathrm{~b}\right)$. The maximum current density reached $-1.52 \pm 0.24 \mathrm{~mA} \mathrm{~cm}^{-2}$ at $0.19 \pm 0.06 \mathrm{~V}$ (based on a t-distribution with $90 \%$ confidence interval and 3 degrees of freedom), which is about 2.5 times higher than the maximum current density obtained in dissolved $\mathrm{O}_{2}$ in the quiescent electrolyte (Fig. 4b). To investigate the effect of cracks in the catalytic layer on the maximum reduction current, the BODbased biogel on top of the carbon nanoparticles was dried under different atmospheric conditions, because the solvent evaporation rate governs the pattern of cracks.(Mampallil and Eral, 2018) 
When the evaporation rate is lowered by the drying procedure at $25 \pm 5{ }^{\circ} \mathrm{C}$ and humidity about $60 \%$ overnight, fewer cracks are expected, and the maximum catalytic current density obtained is $0.99 \mathrm{~mA} \mathrm{~cm}^{-2}$ at $0.00 \mathrm{~V}$ (Fig. S7a), which represents a decrease of $35 \%$ as compared with the electrode dried at $4{ }^{\circ} \mathrm{C}$. Moreover, when the electrode was quickly dried in vacuum and room temperature, and more cracks were produced, the maximum catalytic current density obtained was $1.43 \mathrm{~mA} \mathrm{~cm}^{-2}$ at $0.11 \mathrm{~V}$ (Fig. S7b), similar to that observed in Fig. 6a. Therefore, we can conclude that the presence and amount of cracks play an important role in the BOD-based biogel/C GDE, promoting an effective bio-three-phase interface for ORR.

a)

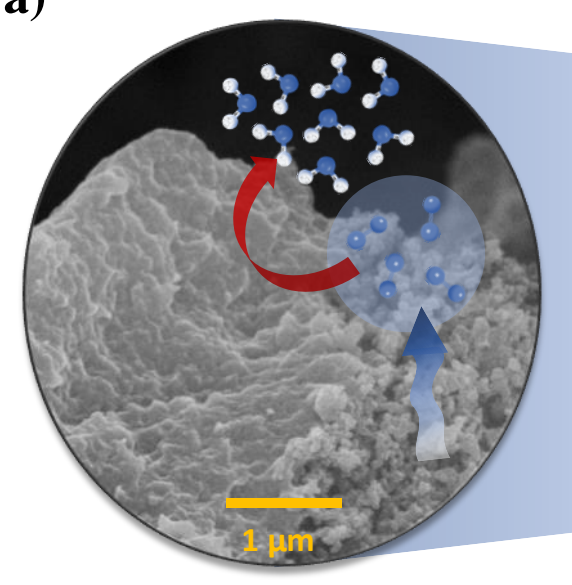

c)

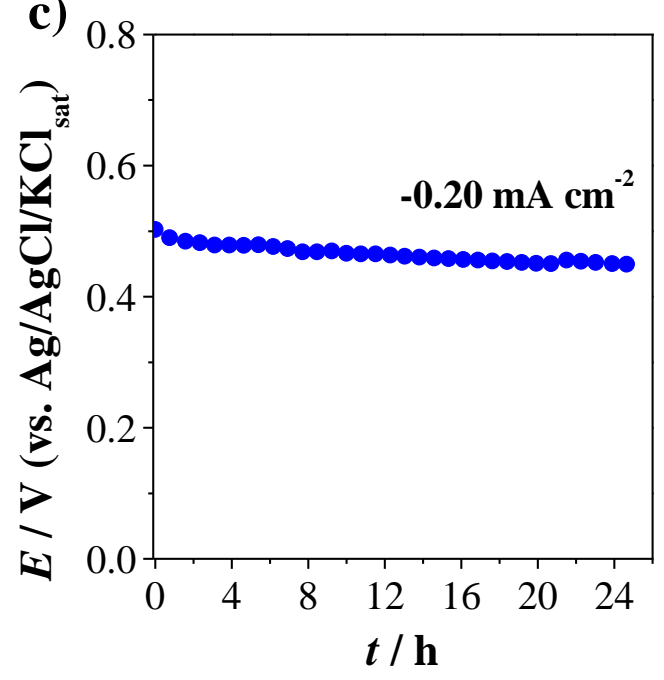

b)

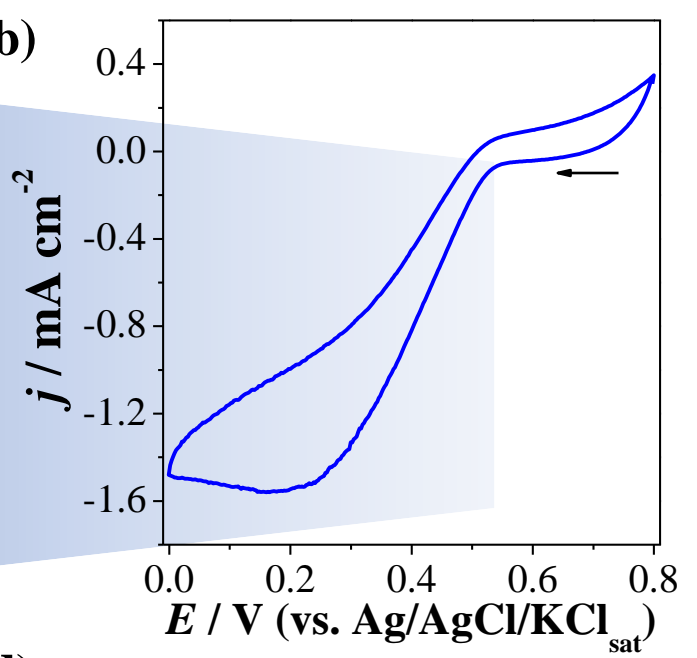

d)

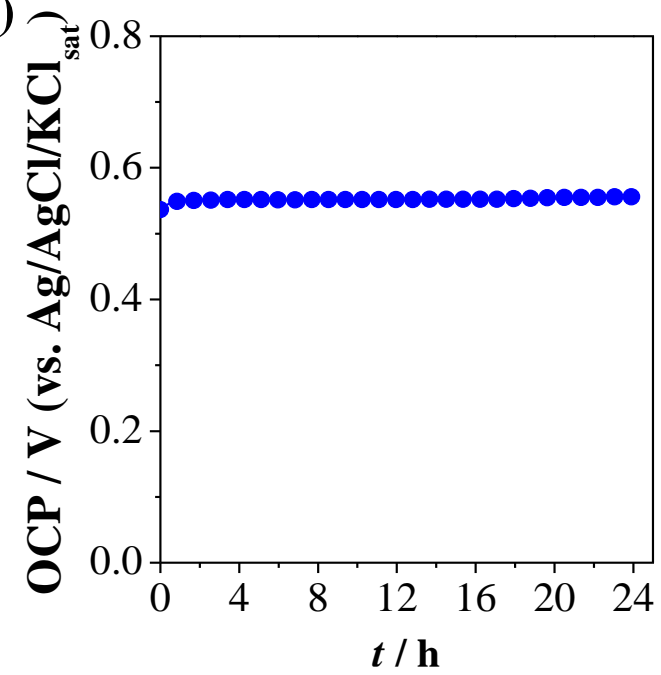

Figure 6. (a) Scheme of ORR on BOD-based biogel/C GDE. The blue and white spheres represent the oxygen and hydrogen atoms, respectively. The blue arrow indicates the diffusion of atmospheric dioxygen and the red arrow represents the ORR catalyzed by BOD-based biogel. (b) $\mathrm{CV}$ at $5 \mathrm{mV} \mathrm{s}^{-1}$, (c) operational stability at $-0.20 \mathrm{~mA} \mathrm{~cm}^{-2}$, and (d) at open circuit potential of the BOD-based biogel/C GDE in phosphate buffer ( $\mathrm{pH} 7.2)$ at $25^{\circ} \mathrm{C}$, under atmospheric condition. 
For practical use, the long-term stability of gas-diffusion bioelectrodes toward ORR is a crucial factor. Although there are some reports(Lalaoui et al., 2016; Poulpiquet et al., 2015; So et al., 2017a, 2016b) that show higher catalytic currents without redox mediators, to the best of our knowledge, none of them details about the longtime performance of the BOD-based GDEs (Table S2), reflecting the challenge of simultaneously attaining long-term stability and satisfactory catalytic current. In this context, the stability of the BOD-based biogel/C GDE was further examined under constant operation (at $-0.20 \mathrm{~mA} \mathrm{~cm}^{-2}$ ) and at open-circuit potential (OCP) conditions, as shown in Figs. 6c and 6d, respectively. Under oxygen reduction conditions, bioelectrode potential starts at $0.50 \mathrm{~V}$, which is the expected potential according to the CV (Fig. $6 \mathrm{~b}$ ), and over $24 \mathrm{~h}$, the potential slightly decreases to $0.45 \pm 0.01 \mathrm{~V}$. Under the open-circuit condition (nonoperation condition), the bioelectrode potential is maintained at $0.55 \mathrm{~V}$ over $24 \mathrm{~h}$. These results show that no considerable enzyme degradation or leaching from the electrode surface occurs over $24 \mathrm{~h}$, demonstrating an unprecedented high stability of a BOD-based electrode under constant operation and OCP conditions.

The satisfactory reduction current density and high electrode stability can be attributed to the stabilization of BOD resulting from confinement in the gel matrix. To demonstrate that, BOD was immobilized on the GDL using the simple drop-casting method, which consists of the direct application of the enzyme solution to the carbon nanoparticles, followed by drying. This traditional method of enzyme immobilization provided a lower catalytic current density (Fig. S8a) and less operational long-term stability (Fig. S8b) compared to the BOD-based biogel/C electrode. Therefore, we can confirm that the BOD confinement in the gel matrix promotes a microenvironment able to maintain the integrity of the molecular structure, allowing a long-term high performance of these bioelectrodes toward ORR, superior to that obtained via traditional bare enzyme immobilization.

\section{Conclusions}

This study shows a simple method for the immobilization and stabilization of BOD for application in a carbon-based gas-diffusion bioelectrode toward dioxygen reduction. The enzyme was incorporated into a gel matrix by the BOD crosslinking inside of a polymeric matrix composed of GA and Nafion. The microscopic and spectroscopic measurements showed that the BOD-based 
biogel prevents the formation of enzyme aggregates on hydrophobic surfaces by suppressing the coffee-ring effect. Additionally, the electrochemical measurements showed that the biogel creates a suitable microenvironment for the DET-type bioelectrocatalysis of BOD toward four-electron electrochemical ORR. The BOD-based biogel/C GDE showed a satisfactory reduction current density of $-1.52 \pm 0.24 \mathrm{~mA} \mathrm{~cm}^{-2}$ at $0.19 \pm 0.06 \mathrm{~V}$ and unprecedented long-term stability under continuous operation. This study also provides new insights into the enzyme immobilization field for application in bioelectrocalytic systems involving a three-phase reaction (electrolyteelectrode-gas), overcoming the crucial factor of long-term stability for practical applications.

\section{Acknowledgements}

The authors gratefully acknowledge the financial support provided by CNPq, CAPES, and São Paulo Research Foundation - FAPESP (G.C.S process 2015/22973-6, L.J.A.M. process 2017/20493-2, and F.N.C. processes 2019/12053-8 and 2019/15333-1). A.H thanks CAPES-

PNPD for the postdoctoral fellowship. The authors thank Dr. Valdecir A. Paganin from Electrochemistry Group (São Carlos Institute of Chemistry, University of São Paulo) for the technical support in the preparation of the GDL diffusion layer of the electrodes.

\section{References}

Barth, A., 2007. Biophys. Acta 1767, 1073-1101.

Christenson, A., Shleev, S., Mano, N., Heller, A., Gorton, L., 2006. Biochim. Biophys. Acta, Bioenerg. 1757, 1634-1641.

Ciniciato, G.P.M.K., Lau, C., Cochrane, A., Sibbett, S.S., Gonzalez, E.R., Atanassov, P., 2012. Electrochim. Acta 82, 208-213.

Crivoi, A., Duan, F., 2013. Phys. Rev. E 87, 042303.

Dos Santos, L., Climent, V., Blanford, C.F., Armstrong, F.A., 2010. Phys. Chem. Chem. Phys. $12,13962-74$.

Guo, D., Fu, S., Dai, Z., 2010. J. Mater. Chem. 20, 10159-10168.

Gupta, G., Lau, C., Branch, B., Rajendran, V., Ivnitski, D., Atanassov, P., 2011a. Electrochim. Acta 56, 10767-10771.

Gupta, G., Lau, C., Rajendran, V., Colon, F., Branch, B., Ivnitski, D., Atanassov, P., 2011 b. Electrochem. Commun. 13, 247-249.

Horst, A.E.W., Mangold, K.M., Holtmann, D., 2016. Biotechnol. Bioeng. 113, 260-267.

Hu, H., Xin, J.H., Hu, H., Chan, A., He, L., 2013. Carbohydr. Polym. 91, 305-313.

Ivnitski, D., Artyushkova, K., Atanassov, P., 2008. Bioelectrochemistry 74, 101-110.

Katchalski-katzir, E., 1993. Trends Biotechnol. 11, 471-478. 
Kil'deeva, N.R., Perminov, P.A., Vladimirov, L. V., Novikov, V. V., Mikhailov, S.N., 2009.

Russ. J. Bioorganic Chem. 35, 360-369.

Kishore, D., Talat, M., Srivastava, O.N., Kayastha, A.M., 2012. PLoS One 7, e40708.

Klinedinst, K.A., Vogel, W.M., Stonehart, P., 1976. J. Mater. Sci. 11, 794-800.

Klotzbach, T.L., Watt, M., Ansari, Y., Minteer, S.D., 2008. J. Memb. Sci. 311, 81-88.

Lalaoui, N., Holzinger, M., Goff, A. Le, Cosnier, S., 2016. Chem. - Eur. J. 22, 10494-10500.

Lalaoui, N., Le Goff, A., Holzinger, M., Cosnier, S., 2015. Chem. - Eur. J. 21, 16868-16873.

Lau, C., Adkins, E.R., Ramasamy, R.P., Luckarift, H.R., Johnson, G.R., Atanassov, P., 2012. Adv. Energy Mater. 2, 162-168.

Li, H., Buesen, D., Williams, R., Henig, J., Stap, S., Mukherjee, K., Freier, E., Lubitz, W., Winkler, M., Happe, T., Plumeré, N., 2018. Chem. Sci. 9, 7596-7605.

Lopez, R.J., Babanova, S., Ulyanova, Y., Singhal, S., Atanassov, P., 2014. ChemElectroChem 1, 241-248.

Luz, R.A.S., Pereira, A.R., de Souza, J.C.P., Sales, F.C.P.F., Crespilho, F.N., 2014. ChemElectroChem 1, 1751-1777.

Macedo, L.J.A., Crespilho, F.N., 2018. Anal. Chem. 90, 1487-1491.

Macedo, L.J.A., Hassan, A., Sedenho, G.C., Crespilho, F.N., 2020. Nat. Commun. 11, 316.

Mampallil, D., Eral, H.B., 2018. Adv. Colloid Interface Sci. 252, 38-54.

Migneault, I., Dartiguenave, C., Bertrand, M.J., Waldron, K.C., 2004. Biotechniques 37, 798802.

Paganin, V.A., Ticianelli, E.A., Gonzalez, E.R., 1996. J. Appl. Electrochem. 26, 297-304.

Poulpiquet, A. De, Haddad, R., Goff, A. Le, Holzinger, M., Mermoux, M., Infossi, P., Mano, N., Lojou, E., Cosnier, S., 2015. Chem. Commun. 51, 7447-7450.

Ramaswamy, N., Arruda, T.M., Wen, W., Hakim, N., Saha, M., Gullá, A., Mukerjee, S., 2009. Electrochim. Acta 54, 6756-6766.

Ramírez, P., Mano, N., Andreu, R., Ruzgas, T., Heller, A., Gorton, L., Shleev, S., 2008. Biochim. Biophys. Acta, Bioenerg. 1777, 1364-1369.

Rasmussen, M., Abdellaoui, S., Minteer, S.D., 2016. Biosens. Bioelectron. 76, 91-102.

Santoro, C., Babanova, S., Erable, B., Schuler, A., Atanassov, P., 2016. Bioelectrochemistry 108, $1-7$.

Schubert, K., Goebel, G., Lisdat, F., 2009. Electrochim. Acta 54, 3033-3038.

Sheldon, R.A., Pelt, S. van, 2013. Chem. Soc. Rev. 42, 6223-6235.

Shleev, S., El Kasmi, A., Ruzgas, T., Gorton, L., 2004. Electrochem. Commun. 6, 934-939.

So, K., Kitazumi, Y., Shirai, O., Kano, K., 2016a. J. Electroanal. Chem. 783, 316-323.

So, K., Onizuka, M., Komukai, T., Kitazumi, Y., Shirai, O., Kano, K., 2016b. Electrochem. Commun. 66, 58-61.

So, K., Ozawa, H., Onizuka, M., Komukai, T., Kitazumi, Y., Shiraia, O., Kano, K., 2017 a. Electrochim. Acta 246, 794-799.

So, K., Sakai, K., Kano, K., 2017b. Curr. Opin. Electrochem. 5, 173-182.

Torres, R., Barbosa, O., Ortiz, C., Berenguer-Murci, Á., Torres, R., Rodrigues, R.C., FernandezLafuente, R., 2014. RSC Adv 4, 1583-1600.

Tsujimura, S., Kano, K., Ikeda, T., 2005a. J. Electroanal. Chem. 576, 113-120.

Tsujimura, S., Kuriyama, A., Fujieda, N., Kano, K., Ikeda, T., 2005b. Anal. Biochem. 337, 325331.

Weigel, M.C., Tritscher, E., Lisdat, F., 2007. Electrochem. Commun. 9, 689-693.

Xia, H., Kitazumi, Y., Shirai, O., Kano, K., 2016. J. Electroanal. Chem. 763, 104-109. 
Xiao, X., Xia, H., Wu, R., Bai, L., Yan, L., Magner, E., Cosnier, S., Lojou, E., Zhu, Z., Liu, A., 2019. Chem. Rev. 119, 9509-9558.

Xing, W., Yin, G., Zhang, J., 2014. Rotating Electrode Methods and Oxygen Reduction Electrocatalysts, 1st ed. Elsevier, Amsterdam, The Netherlands.

Yates, N.D.J., Fascione, M.A., Parkin, A., 2018. Chem. - Eur. J. 24, 12164-12182. 


\section{Supplementary Material}

\section{Stabilization of Bilirubin Oxidase in a Biogel Matrix for High-performance Gas Diffusion Electrodes}

Graziela C. Sedenho, Ayaz Hassan, Lucyano J. A. Macedo and Frank N. Crespilho*

São Carlos Institute of Chemistry, University of São Paulo (USP), São Carlos, SP 13560-970, Brazil.

*E-mail: frankcrespilho@iqsc.usp.br; +55 1633738783.
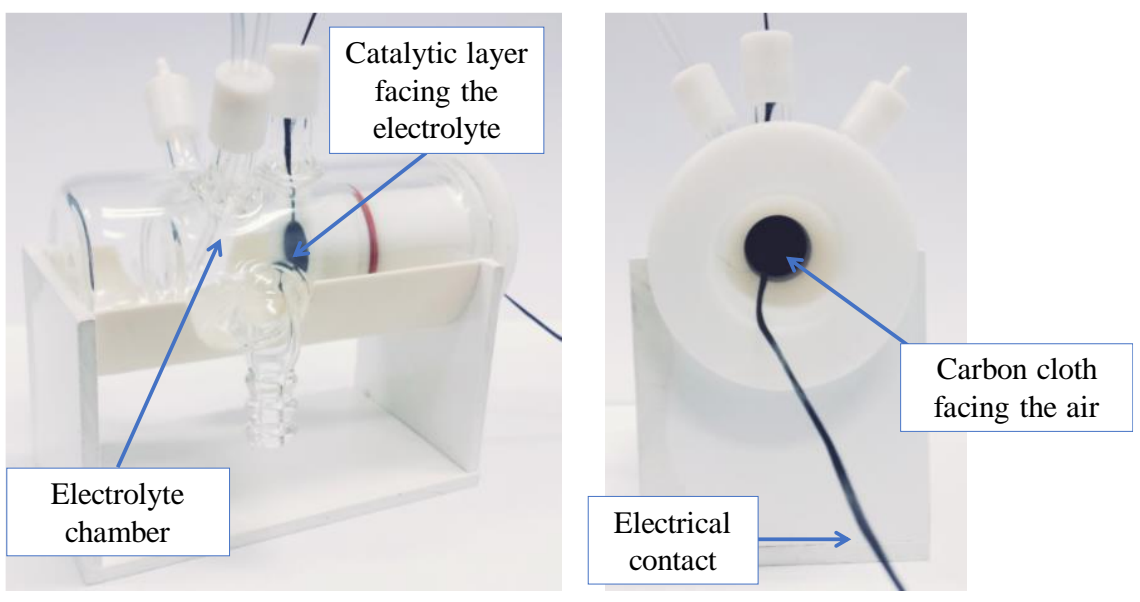

Figure S1. Homemade glass electrochemical used in the gas-diffusion experiments. 
Table S1. Vibrational modes assignment of the various functional groups of BOD-based biogel components observed in the FTIR spectra.

\begin{tabular}{|c|c|c|c|}
\hline Compound & $\begin{array}{c}\text { Band position } \\
\left(\mathrm{cm}^{-1}\right)\end{array}$ & Attribution & Reference \\
\hline \multirow[t]{6}{*}{ Nafion } & 1643 & $\mathrm{O}-\mathrm{H}$ bending & $\begin{array}{c}\text { (Guo et al., } \\
\text { 2010) }\end{array}$ \\
\hline & 1315 & $\mathrm{~S}=\mathrm{O}$ asymmetric stretching & $\begin{array}{l}\text { (Ramaswamy } \\
\text { et al., 2009) }\end{array}$ \\
\hline & 1233 & $\mathrm{CF}_{2}$ asymmetric stretching & $\begin{array}{l}\text { (Ramaswamy } \\
\text { et al., 2009) }\end{array}$ \\
\hline & 1150 & $\mathrm{CF}_{2}$ symmetric stretching & $\begin{array}{c}\text { (Ramaswamy } \\
\text { et al., 2009) }\end{array}$ \\
\hline & 1060 & $\mathrm{O}=\mathrm{S}(\mathrm{O})=\mathrm{O}$ symmetric stretching & $\begin{array}{l}\text { (Ramaswamy } \\
\text { et al., 2009) }\end{array}$ \\
\hline & 980 & C-O-C stretching & $\begin{array}{l}\text { (Ramaswamy } \\
\text { et al., 2009) }\end{array}$ \\
\hline \multirow[t]{4}{*}{ GA } & 1713 & $\mathrm{C}=\mathrm{O}$ stretching & $\begin{array}{c}\text { (Kil'deeva et } \\
\text { al., 2009) }\end{array}$ \\
\hline & 1677 & $\mathrm{O}-\mathrm{H}$ bending & $\begin{array}{c}\text { (Hu et al., } \\
\text { 2013) }\end{array}$ \\
\hline & 1453 & $\mathrm{CH}_{2}$ bending & $\begin{array}{c}\text { (Hu et al., } \\
\text { 2013) }\end{array}$ \\
\hline & 1405 & $\mathrm{C}-\mathrm{H}$ bending & $\begin{array}{c}\text { (Hu et al., } \\
\text { 2013) }\end{array}$ \\
\hline
\end{tabular}




\begin{tabular}{|c|c|c|c|}
\hline & 1128 & $\mathrm{C}=\mathrm{O}$ deformation & $\begin{array}{c}\text { (Hu et al., } \\
\text { 2013) }\end{array}$ \\
\hline & 1063 & C-O stretching (from alcohol) & $\begin{array}{c}\text { (Kishore et } \\
\text { al., 2012) }\end{array}$ \\
\hline \multirow[t]{5}{*}{ BOD } & 1663 & $\begin{array}{l}\text { Amide-I }(\mathrm{C}=\mathrm{O} \text { stretching vibration with } \\
\text { minor contributions from the out-of-phase } \mathrm{C} \text { - } \\
\mathrm{N} \text { stretching vibration, the } \mathrm{C}-\mathrm{C}-\mathrm{N} \\
\text { deformation and the } \mathrm{N}-\mathrm{H} \text { in-plane bend) }\end{array}$ & (Barth, 2007) \\
\hline & 1543 & $\begin{array}{l}\text { Amide-II (out-of-phase combination of the } \\
\mathrm{N}-\mathrm{H} \text { in plane bend and the } \mathrm{C}-\mathrm{N} \text { stretching } \\
\text { vibration with smaller contributions from the } \\
\mathrm{C}=\mathrm{O} \text { in plane bend and the } \mathrm{C}-\mathrm{C} \text { and } \mathrm{N}-\mathrm{C} \\
\text { stretching vibrations) }\end{array}$ & (Barth, 2007) \\
\hline & 1456 & $\mathrm{CH}_{3}$ asymmetric bending & (Barth, 2007) \\
\hline & 1253 & $\mathrm{CH}_{2}$ wagging & (Barth, 2007) \\
\hline & 1104 & C-C stretching & (Barth, 2007) \\
\hline
\end{tabular}



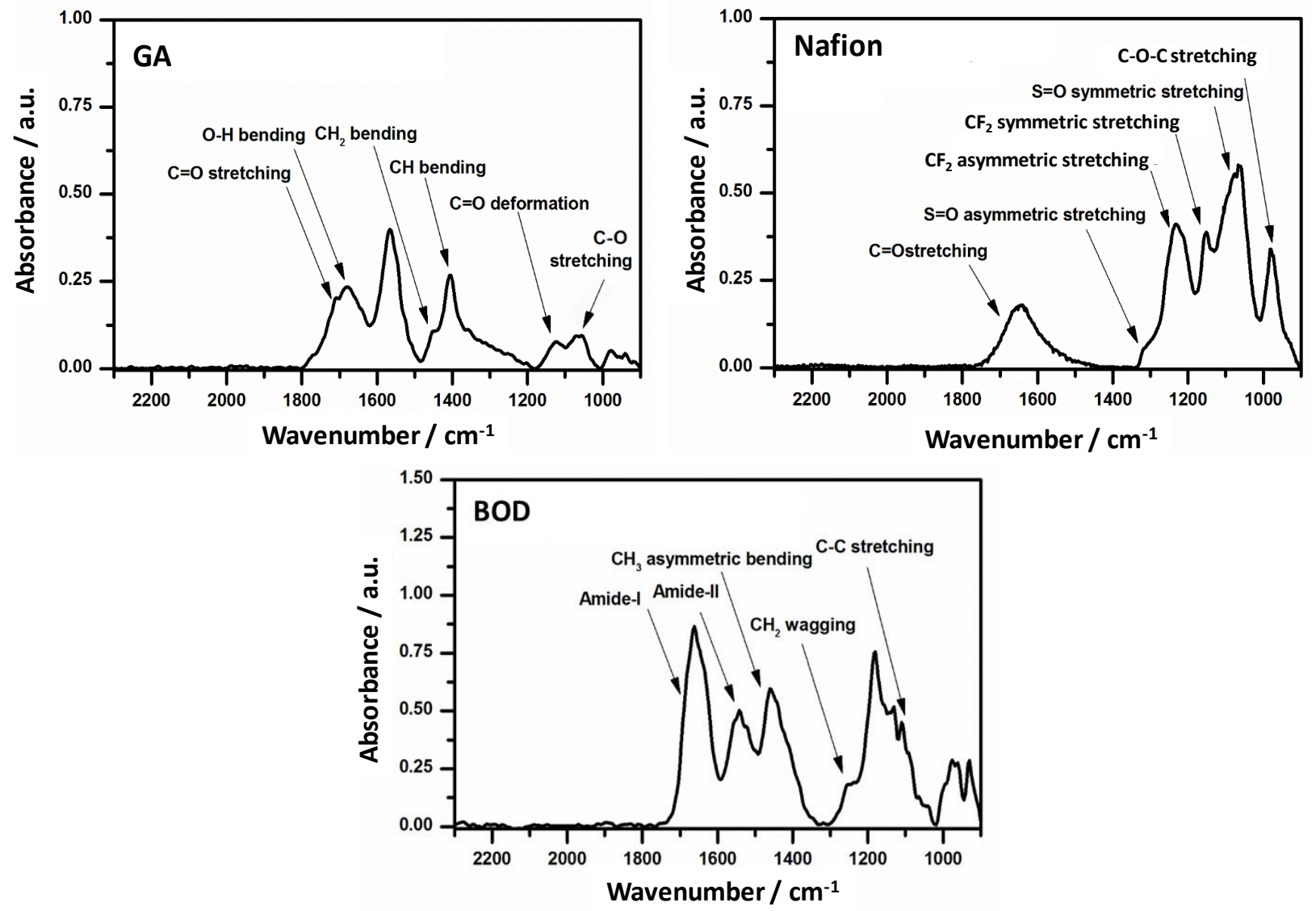

Figure S2. FTIR spectra of the components of BOD-based biogel.

$\overbrace{\mathrm{H}}^{\stackrel{\mathrm{H}_{2} \mathrm{O}}{\rightleftarrows}}$<smiles>C[13CH2][13C@H](O)[18OH]</smiles>

(Equation S2)

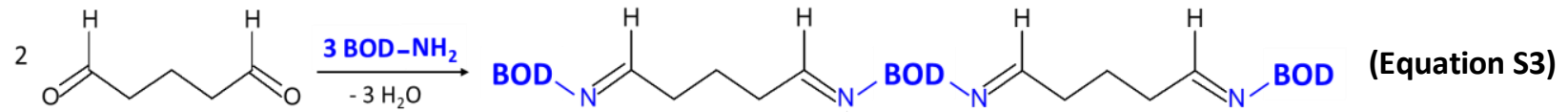



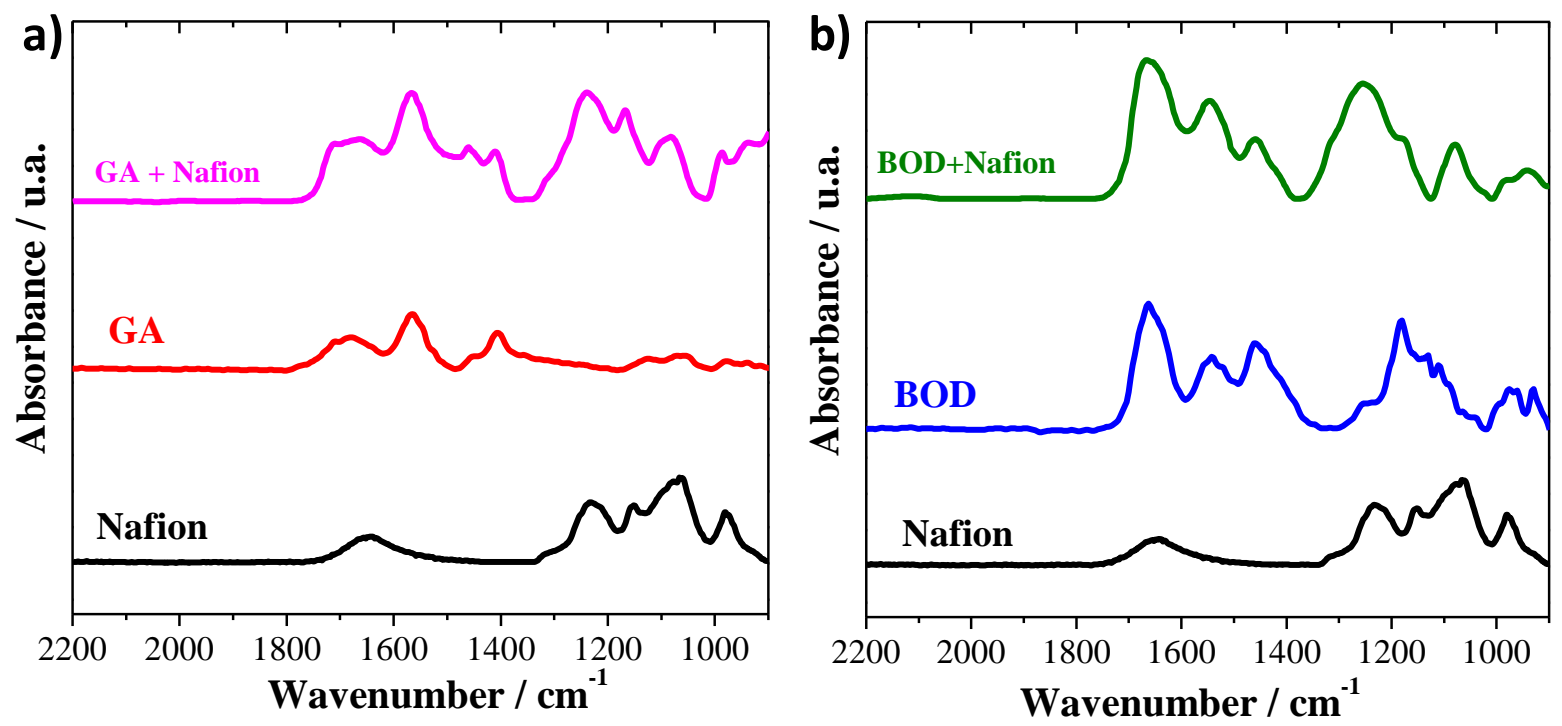

Figure S3. FTIR spectra of (a) Nafion, GA and their mixture, and (b) Nafion, BOD and their mixture.

a)

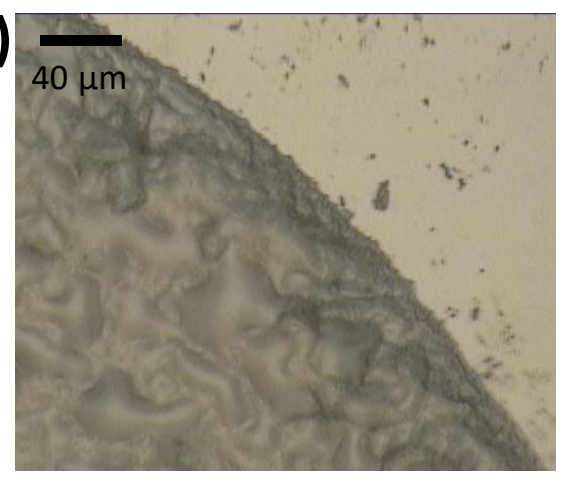

b)

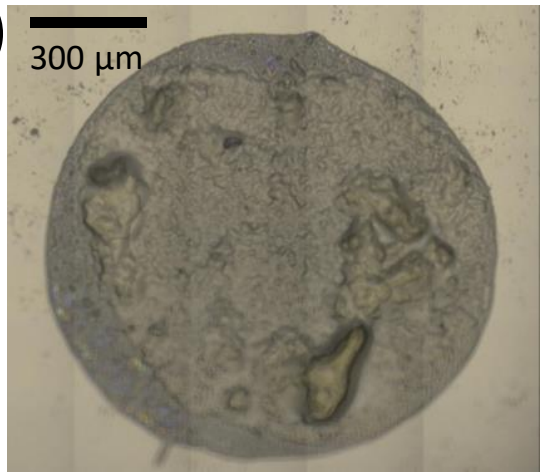

c)

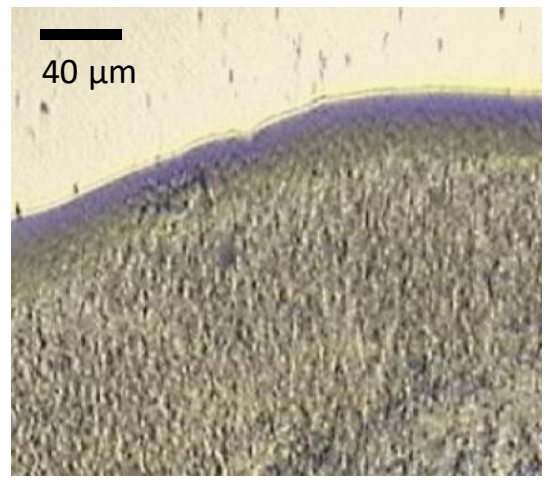

d)

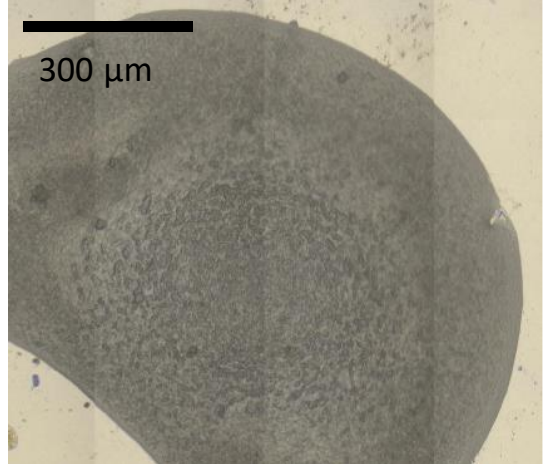

Figure S4. Optical microscopic images obtained in the reflectance mode of BOD-based biogel $(a, b)$ and bare-BOD (c, d) films obtained by drop-casting on GC substrate. 


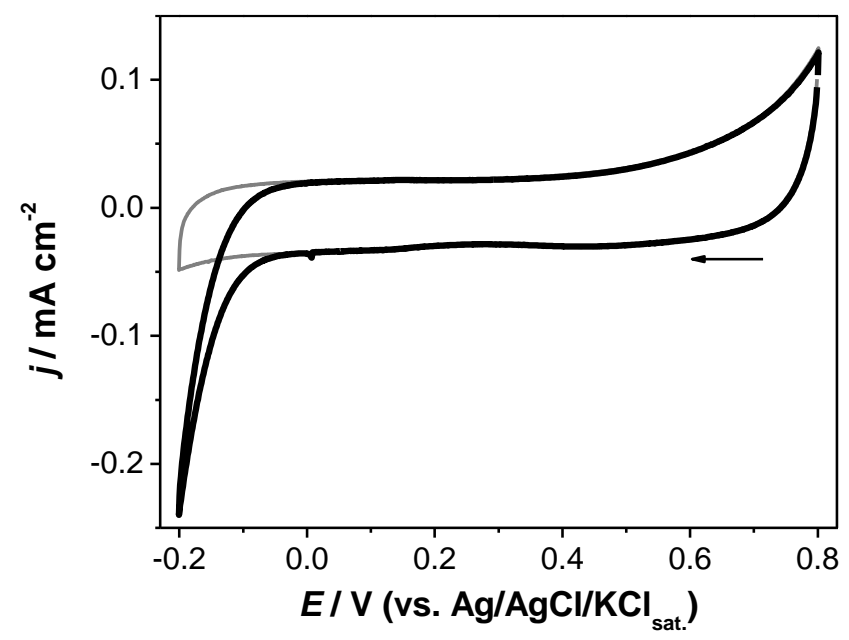

Figure S5. CVs at $5 \mathrm{mV} \mathrm{s}^{-1}$ obtained with enzyme-free carbon electrode in phosphate buffer $\mathrm{pH}$ 7.2 at $25^{\circ} \mathrm{C}$ saturated with $\mathrm{O}_{2}$ (black curve) and with Ar (gray curve).

$$
j_{\mathrm{mt}}=-0.62 \mathrm{n}_{\mathrm{s}} \mathrm{FD}_{\mathrm{o}}^{\frac{2}{3}} \mathrm{v}^{-\frac{1}{6}} \omega^{\frac{1}{2}} \mathrm{C}_{\mathrm{o}} \quad \text { (Equation S4) }
$$

where, $n_{s}, \mathrm{~F}, \mathrm{D}_{\mathrm{o}}, \mathrm{v}, \omega$, and $\mathrm{C}_{\mathrm{o}}$, are the number of electrons involved in the substrate redox reaction, the Faraday constant, the diffusion coefficient of $\mathrm{O}_{2}\left(1.7 \times 10^{-5} \mathrm{~cm}^{2} \mathrm{~s}^{-1}\right.$, at $25^{\circ} \mathrm{C}$ in aqueous solution), the kinematic viscosity of water $\left(0.01 \mathrm{~cm}^{2} \mathrm{~s}^{-1}\right.$, at $\left.25^{\circ} \mathrm{C}\right)$, the rotation rate, and the concentration of dissolved $\mathrm{O}_{2}\left(1.2 \mathrm{mmol} \mathrm{L}^{-1}\right.$, at $25^{\circ} \mathrm{C}$, in aqueous solution).

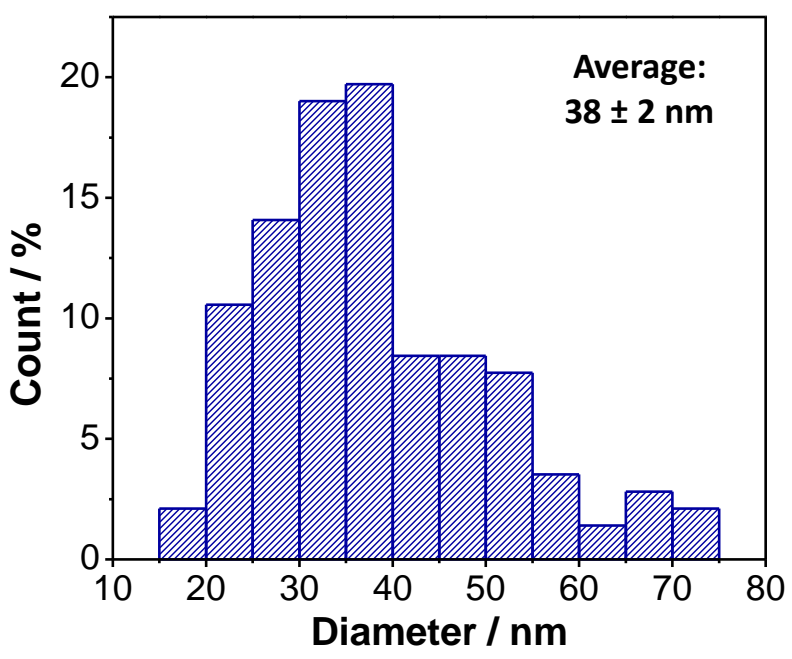


Figure S6. High resolution SEM images of the carbon nanoparticle layer (a-b) and histogram of the carbon nanoparticle diameter $(\mathrm{c})$.
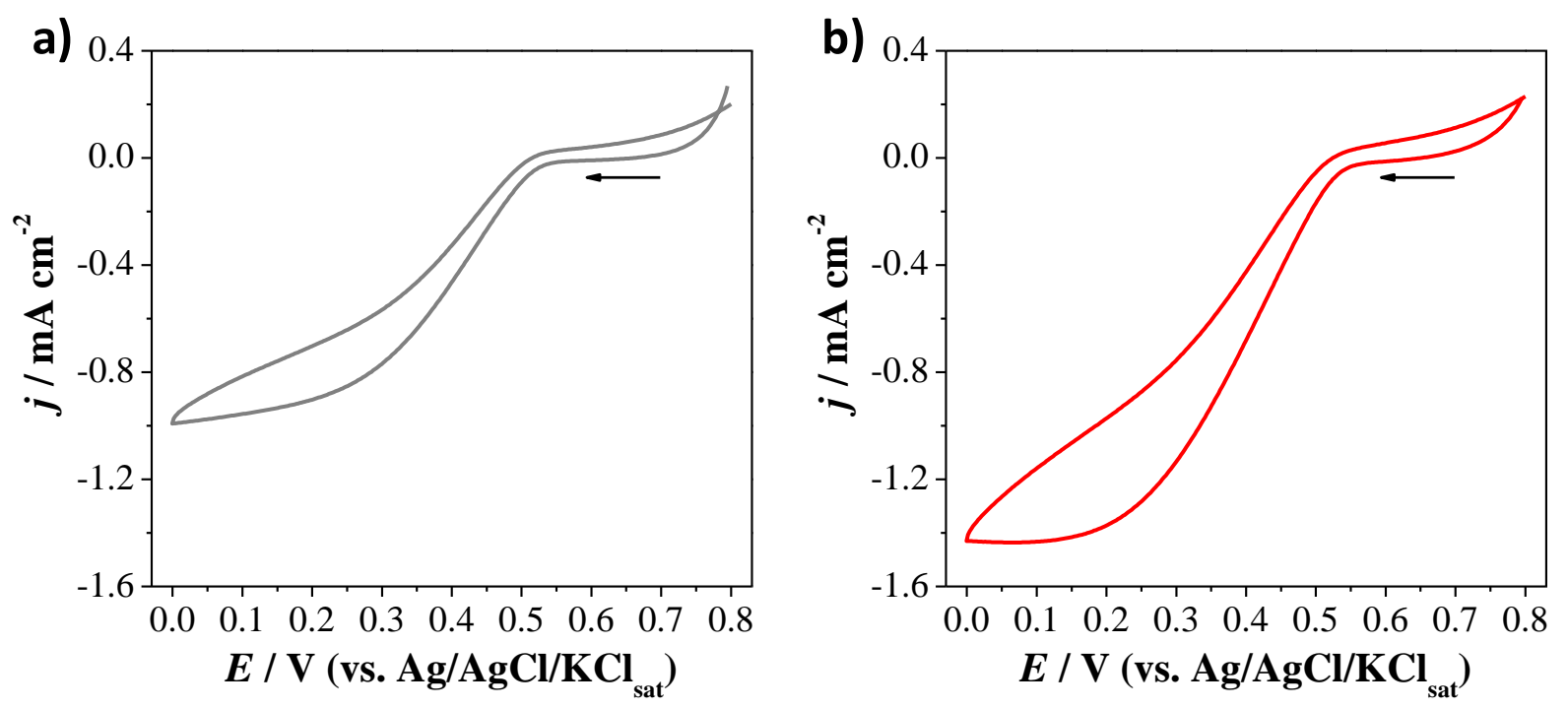

Figure S7. CV at $5 \mathrm{mV} \mathrm{s}^{-1}$ of (a) BOD-based biogel/C GDE dried at room temperature and humidity (about (60\%) and (b) dried at vacuum and room. CVs recorded in phosphate buffer ( $\mathrm{pH}$ 7.2) at $25^{\circ} \mathrm{C}$, under atmospheric condition.
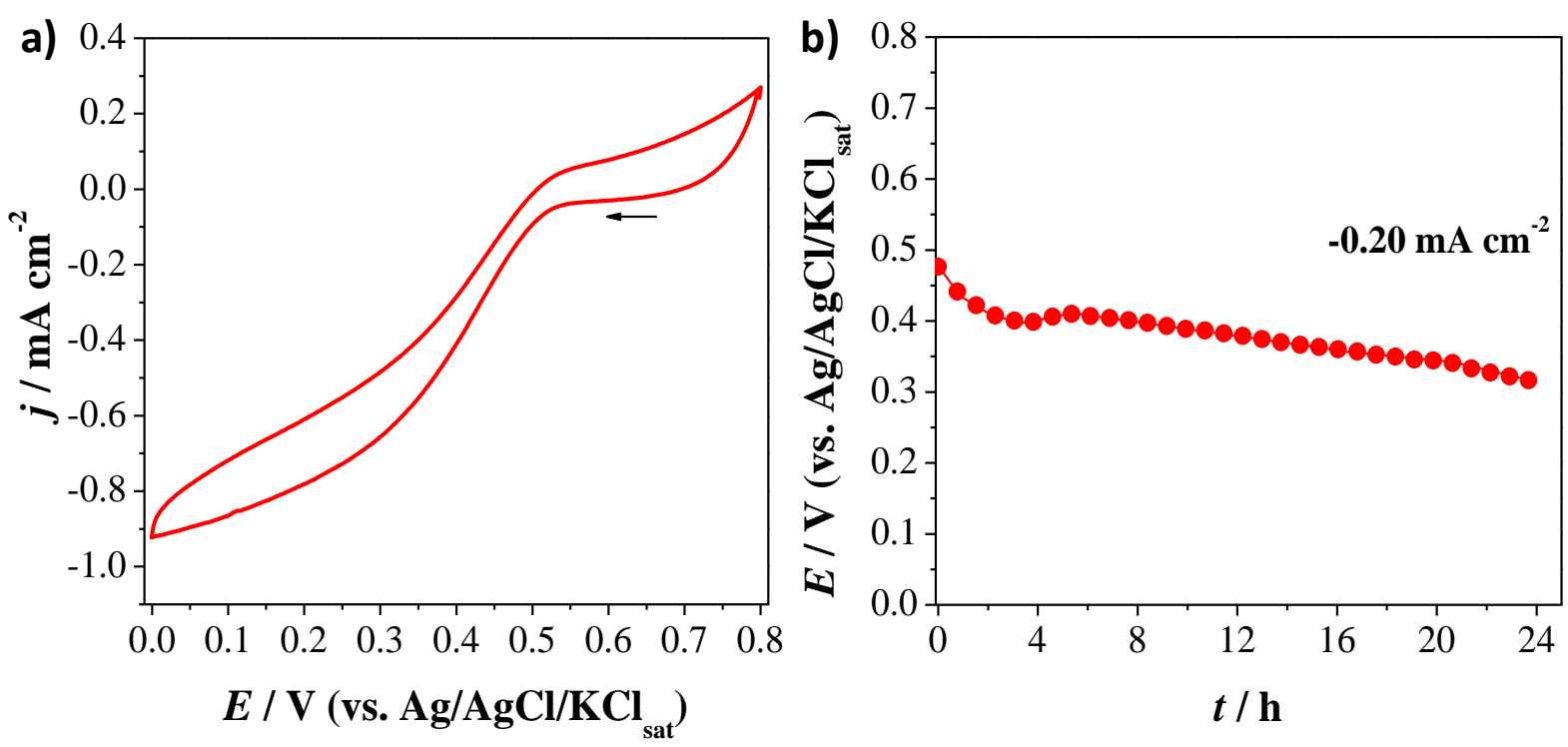

Figure S8. (a) $\mathrm{CV}$ at $5 \mathrm{mV} \mathrm{s}^{-1}$ and (b) long-term operational stability at $-0.20 \mathrm{~mA} \mathrm{~cm}^{-2}$ of $\mathrm{BOD} / \mathrm{C}$ gas-diffusion electrode in phosphate buffer $(\mathrm{pH} 7.2)$ at $25^{\circ} \mathrm{C}$, under atmospheric condition. 
Table S2. Performance of BOD-based gas diffusion electrodes towards ORR without redox mediator.

\begin{tabular}{|c|c|c|c|c|c|c|}
\hline \multirow[b]{2}{*}{$\begin{array}{l}\text { Carbon-based } \\
\text { material }\end{array}$} & \multicolumn{2}{|l|}{ Conditions } & \multirow[b]{2}{*}{$\begin{array}{l}\text { Current density / } \\
\mathrm{mA} \mathrm{cm}\end{array}$} & \multirow[b]{2}{*}{$\begin{array}{l}\text { Measurement } \\
\text { method }\end{array}$} & \multirow[b]{2}{*}{ Reported stability } & \multirow[b]{2}{*}{ Ref. } \\
\hline & Electrolyte & $\begin{array}{l}\text { Gas } \\
\text { phase }\end{array}$ & & & & \\
\hline $\begin{array}{l}\text { Carbon } \\
\text { nanoparticle }\end{array}$ & $\begin{array}{l}\text { Phosphate buffer, } \\
0.1 \mathrm{~mol} \mathrm{~L}^{-1}, \mathrm{pH} \\
7.2,25^{\circ} \mathrm{C} \text {. }\end{array}$ & Air & $\begin{array}{l}-1.52 \pm 0.24 \text { at } \\
0.19 \pm 0.06 \mathrm{~V}\end{array}$ & $\mathrm{CV}$ at $5 \mathrm{mV} \mathrm{s}^{-1}$ & $\begin{array}{l}24 \mathrm{~h} \text { at }-200 \mu \mathrm{A} \mathrm{cm}^{-2}: 0.55 \mathrm{~V} \text {; } \\
24 \mathrm{~h} \text { at OCP: } 0.50-0.45 \mathrm{~V}\end{array}$ & This work \\
\hline MWCNT & $\begin{array}{l}\text { Phosphate buffer, } \\
0.2 \mathrm{~mol} \mathrm{~L}-1, \mathrm{pH} \\
7.2,45^{\circ} \mathrm{C} \text {. }\end{array}$ & Air & $3.0 \pm 0.2$ at $0 \mathrm{~V}$ & $\begin{array}{l}\mathrm{CV} \text { at } \\
10 \mathrm{mV} \mathrm{s}^{-1}\end{array}$ & N.A. & $\begin{array}{c}\text { (Poulpiquet et al., } \\
\text { 2015) }\end{array}$ \\
\hline MWCNT & $\begin{array}{l}\text { Citrate buffer } 1.5 \\
\text { mol L }{ }^{-1} \text {, } \\
\text { pH } 5 \text {, at } 40{ }^{\circ} \mathrm{C} \text {. }\end{array}$ & $\begin{array}{l}\text { Pure } \\
\mathrm{O}_{2}\end{array}$ & 15 at $0 \mathrm{~V}$ & $\begin{array}{l}\mathrm{CV} \text { at } \\
10 \mathrm{mV} \mathrm{s}^{-1}\end{array}$ & N.A. & (So et al., 2016b) \\
\hline $\begin{array}{l}\text { Functionalized } \\
\text { MWCNT }\end{array}$ & $\begin{array}{l}\text { Mc Ilvaine buffer, } \\
\text { pH } 7 .\end{array}$ & Air & $3.9 \pm 0.5$ at $0 \mathrm{~V}$ & $\begin{array}{l}\mathrm{CV} \text { at } \\
10 \mathrm{mV} \mathrm{s}^{-1}\end{array}$ & N.A. & $\begin{array}{l}\text { (Lalaoui et al., } \\
\text { 2016) }\end{array}$ \\
\hline Hollow CNT & $\begin{array}{l}\text { Citrate buffer } 1.5 \\
\text { mol L }{ }^{-1} \text {, } \\
\text { pH 5.0, at } 40{ }^{\circ} \mathrm{C} \text {. }\end{array}$ & $\begin{array}{l}\text { Pure } \\
\mathrm{O}_{2}\end{array}$ & 30 at $0 \mathrm{~V}$ & $\begin{array}{l}\mathrm{LSV} \text { at } \\
10 \mathrm{mV} \mathrm{s}^{-1}\end{array}$ & $\begin{array}{l}60 \mathrm{~s} \text { at } 0 \mathrm{~V} \text {, catalytic current } \\
\text { gradually decreases with time. }\end{array}$ & (So et al., 2017) \\
\hline Ketjen black & $\begin{array}{l}\text { Citrate buffer } 1.5 \\
\text { mol L } \\
\text { pH } 5 \text { at } 40{ }^{\circ} \mathrm{C} \text {. }\end{array}$ & $\begin{array}{l}\text { Pure } \\
\mathrm{O}_{2}\end{array}$ & 20 at $0 \mathrm{~V}$ & $\begin{array}{l}\mathrm{CV} \text { at } \\
10 \mathrm{mV} \mathrm{s}^{-1}\end{array}$ & $\begin{array}{l}60 \mathrm{~s} \text { at } 0 \mathrm{~V} \text {, catalytic current } \\
\text { gradually decreases with time. }\end{array}$ & (So et al., 2016a) \\
\hline
\end{tabular}




\begin{tabular}{|c|c|c|c|c|c|c|}
\hline $\begin{array}{l}\text { Functionalized } \\
\text { Ketjen black }\end{array}$ & $\begin{array}{l}\text { Citrate buffer } 1.5 \\
\text { mol L }{ }^{-1} \\
\text { pH } 5 \text { at } 25^{\circ} \mathrm{C} .\end{array}$ & Air & 30 at $0 \mathrm{~V}$ & $\mathrm{CA}$ at $0 \mathrm{~V}$ & $\begin{array}{l}60 \mathrm{~s} \text { at } 0 \mathrm{~V} \text { : decays from } 30 \text { to } \\
8.0 \mathrm{~mA} \mathrm{~cm} \mathrm{~m}^{-2} \text {. }\end{array}$ & (Xia et al., 2016) \\
\hline $\begin{array}{l}\text { MWCNT } \\
\text { paper } \\
\text { (Buckeye } \\
\text { paper) }\end{array}$ & $\begin{array}{l}\text { Phosphate buffer, } \\
0.05 \mathrm{~mol} \mathrm{~L}^{-1}, \mathrm{pH} \\
7.5,0.1 \mathrm{~mol} \mathrm{~L}^{-1} \\
\mathrm{KCl} \text {. }\end{array}$ & Air & 0.35 at $0.3 \mathrm{~V}$ & $\mathrm{CA}$ at $0.3 \mathrm{~V}$ & $\begin{array}{l}45 \text { days at } 0.3 \mathrm{~V} \text {. } \\
\text { Decays: } \\
\text { 3 days: } 60 \mu \mathrm{Acm}^{-2} \text { day }^{-1} \text {; } \\
\text { 3-9 days: } 10 \mu \mathrm{Acm}^{-2} \text { day }^{-1} \text {; } \\
\text { 9-45 days: } 1.5 \mu \mathrm{Acm}^{-2} \text { day }^{-1} \text {. }\end{array}$ & $\begin{array}{l}\text { (Santoro et al., } \\
\text { 2016) }\end{array}$ \\
\hline $\begin{array}{l}\text { Highly } \\
\text { conductive } \\
\text { Buckeye paper }\end{array}$ & $\begin{array}{l}\text { Phosphate buffer, } \\
0.1 \mathrm{~mol} \mathrm{~L}^{-1}, \mathrm{pH} 7 \text {, } \\
25^{\circ} \mathrm{C} \text {. }\end{array}$ & Air & $\begin{array}{l}0.475 \pm 0.09 \text { at } \\
0 \mathrm{~V}\end{array}$ & $\mathrm{CA}$ at $0 \mathrm{~V}$ & $\begin{array}{l}10 \mathrm{~h} \text { at } 0.3 \mathrm{~V}: \\
200 \pm 6 \mu \mathrm{A} \mathrm{cm}^{-2}\end{array}$ & $\begin{array}{l}\text { (Ciniciato et al., } \\
\text { 2012) }\end{array}$ \\
\hline
\end{tabular}

MWCNT: multi-walled carbon nanotube; CV: cyclic voltammetry; LSV: linear sweep voltammetry; CA: chronoamperometry. 


\section{References}

Barth, A., 2007. Infrared spectroscopy of proteins. Biochim. Biophys. Acta 1767, 1073-1101.

Ciniciato, G.P.M.K., Lau, C., Cochrane, A., Sibbett, S.S., Gonzalez, E.R., Atanassov, P., 2012.

Development of paper based electrodes: From air-breathing to paintable enzymatic cathodes. Electrochim. Acta 82, 208-213.

Guo, D., Fu, S., Dai, Z., 2010. A highly porous nafion membrane templated from polyoxometalates-based supramolecule composite for ion-exchange polymer-metal composite actuator. J. Mater. Chem. 20, 10159-10168.

Hu, H., Xin, J.H., Hu, H., Chan, A., He, L., 2013. Glutaraldehyde - chitosan and poly (vinyl alcohol) blends, and fluorescence of their nano-silica composite films. Carbohydr. Polym. 91, 305-313.

Kil'deeva, N.R., Perminov, P.A., Vladimirov, L. V., Novikov, V. V., Mikhailov, S.N., 2009. On the Mechanism of the Reaction of Glutaraldehyde with Chitosan. Russ. J. Bioorganic Chem. $35,360-369$.

Kishore, D., Talat, M., Srivastava, O.N., Kayastha, A.M., 2012. Immobilization of bGalactosidase onto Functionalized Graphene Nano-sheets Using Response Surface Methodology and Its Analytical Applications. PLoS One 7, e40708.

Lalaoui, N., Holzinger, M., Goff, A. Le, Cosnier, S., 2016. Diazonium Functionalisation of Carbon Nanotubes for Specific Orientation of Multicopper Oxidases: Controlling Electron Entry Points and Oxygen Diffusion to the Enzyme. Chem. Eur. J. 22, 10494-10500.

Poulpiquet, A. De, Haddad, R., Goff, A. Le, Holzinger, M., Mermoux, M., Infossi, P., Mano, N., Lojou, E., Cosnier, S., 2015. A membraneless air-breathing hydrogen biofuel cell based on direct wiring of thermostable enzymes on carbon nanotube electrodes. Chem. Commun. 51, $7447-7450$.

Ramaswamy, N., Arruda, T.M., Wen, W., Hakim, N., Saha, M., Gullá, A., Mukerjee, S., 2009. Enhanced activity and interfacial durability study of ultra low Pt based electrocatalysts prepared by ion beam assisted deposition (IBAD) method. Electrochim. Acta 54, 67566766. 
Santoro, C., Babanova, S., Erable, B., Schuler, A., Atanassov, P., 2016. Bilirubin oxidase based enzymatic air-breathing cathode: Operation under pristine and contaminated conditions. Bioelectrochemistry 108, 1-7.

So, K., Kitazumi, Y., Shirai, O., Nishikawa, K., Higuchi, Y., Kano, K., 2016a. Direct electron transfer-type dual gas diffusion H2/O2 biofuel cells. J. Mater. Chem. A 4, 8742-8749.

So, K., Onizuka, M., Komukai, T., Kitazumi, Y., Shirai, O., Kano, K., 2016b. Binder/surfactantfree biocathode with bilirubin oxidase for gas-diffusion-type system. Electrochem. commun. 66, 58-61.

So, K., Ozawa, H., Onizuka, M., Komukai, T., Kitazumi, Y., Shiraia, O., Kano, K., 2017. Highly Permeable Gas Diffusion Electrodes with Hollow Carbon Nanotubes for Bilirubin OxidaseCatalyzed Dioxygen Reduction. Electrochim. Acta 246, 794-799.

Xia, H., So, K., Kitazumi, Y., Shirai, O., Nishikawa, K., 2016. Dual gas-diffusion membraneand mediatorless dihydrogen/air-breathing biofuel cell operating at room temperature. J. Power Sources 335, 105-112. 